\title{
Loopbanen na Maastricht University: metingen 2008 en 2009
}

Citation for published version (APA):

van Breugel, G. A. A., Meng, C. M., \& Ramaekers, G. W. M. (2010). Loopbanen na Maastricht University: metingen 2008 en 2009. Researchcentrum voor Onderwijs en Arbeidsmarkt, Faculteit der Economische Wetenschappen. ROA Reports No. 4 https://doi.org/10.26481/umarep.2010004

Document status and date:

Published: 01/01/2010

DOI:

10.26481/umarep.2010004

Document Version:

Publisher's PDF, also known as Version of record

\section{Please check the document version of this publication:}

- A submitted manuscript is the version of the article upon submission and before peer-review. There can be important differences between the submitted version and the official published version of record.

People interested in the research are advised to contact the author for the final version of the publication, or visit the DOI to the publisher's website.

- The final author version and the galley proof are versions of the publication after peer review.

- The final published version features the final layout of the paper including the volume, issue and page numbers.

Link to publication

\footnotetext{
General rights rights.

- You may freely distribute the URL identifying the publication in the public portal. please follow below link for the End User Agreement:

www.umlib.nl/taverne-license

Take down policy

If you believe that this document breaches copyright please contact us at:

repository@maastrichtuniversity.nl

providing details and we will investigate your claim.
}

Copyright and moral rights for the publications made accessible in the public portal are retained by the authors and/or other copyright owners and it is a condition of accessing publications that users recognise and abide by the legal requirements associated with these

- Users may download and print one copy of any publication from the public portal for the purpose of private study or research.

- You may not further distribute the material or use it for any profit-making activity or commercial gain

If the publication is distributed under the terms of Article $25 \mathrm{fa}$ of the Dutch Copyright Act, indicated by the "Taverne" license above, 


\title{
Loopbanen na Maastricht University: metingen 2008 en 2009
}

\author{
Gerla van Breugel \\ Christoph Meng \\ Ger Ramaekers
}

ROA-R-2010/4 


\section{Colofon}

(C) Researchcentrum voor Onderwijs en Arbeidsmarkt (ROA). Niets uit deze uitgave mag op enige manier worden verveelvoudigd zonder voorafgaande schriftelijke toestemming van de directeur van het ROA.

\section{Researchcentrum voor Onderwijs en Arbeidsmarkt}

School of Business and Economics

Maastricht University

\section{Vormgeving}

ROA secretariaat, Maastricht

email: secretary-roa-sbe@maastrichtuniversity.nl

website: www.roa.nl

ISBN: 978-90-532I-485-5

april 2010 


\section{Inhoud}

Voorwoord $\quad$ v

Samenvatting vii

Summary ix

1 Inleiding 1

1.1 Arbeidsmarktscanner Maastricht University 1

1.2 Leeswijzer 3

2 Actuele arbeidsmarktpositie van Maastrichtse alumni: resultaten metingen 2008-2009

2.1 Huidige maatschappelijke positie en soort dienstverband

2.2 Allocatie op de arbeidsmarkt (waar is men terecht gekomen?) 8

2.3 Opbrengsten van de opleiding op de arbeidsmarkt (extern rendement) 11

$\begin{array}{lll}2.4 & \text { Tevredenheid over werk en opleiding } & 14\end{array}$

$\begin{array}{ll}\text { 2.5 Samenvatting en conclusies } & 17\end{array}$

3 Effect van macro-economische shocks op de arbeidsmarktintrede van

Maastrichtse alumni

$\begin{array}{lll}3.1 \text { Inleiding } & 19\end{array}$

3.2 Kans op werk en baanzekerheid op korte termijn 20

3.3 Aansluiting opleiding-werk en beloning op korte termijn 24

3.4 Alternatieven voor het aanbieden op de arbeidsmarkt: zelfstandig ondernemerschap en doorstroom naar vervolgonderwijs $\quad 30$

3.5 Slechte start op de arbeidsmarkt: Effecten op middellange termijn 32

$\begin{array}{ll}3.6 & \text { Samenvatting en conclusies } \\ \end{array}$

4 Succes- en beschermende factoren voor arbeidsmarktintrede 35

$\begin{array}{lll}4.1 & \text { Inleiding } & 35\end{array}$

4.2 Vakspecifiek of academisch: De arbeidsmarkt van afgestudeerden van Maastricht University 36

4.3 Productie van vakspecifieke en academische competenties in het hoger onderwijs

4.3.1 De rol van de leeromgeving 40

4.3.2 De rol van de werkervaring en stage 43 
4.4 Conclusies

Literatuur

Bijlage 1 


\section{Voorwoord}

Hoe vergaat het alumni van Maastricht University na afstuderen? In dit tweejaarlijkse rapport worden de resultaten gepresenteerd van de in 2008 en 2009 uitgevoerde metingen onder alumni van Maastricht University. Deze betreffen metingen op drie momenten tijdens de loopbaan, namelijk I $1 \frac{1}{2}, 5^{1 / 2}$ en IO $1 \frac{1}{2}$ jaar na afstuderen. Aan de hand hiervan wordt een beeld geschetst van de arbeidsmarktintrede (meting na $\mathrm{I}^{1 / 2}$ jaar), de eerste fase van de loopbaan (meting na $5^{1 / 2}$ jaar) en het verdere verloop van de loopbaan (meting na IO $1 / 2$ jaar) van Maastrichtse alumni.

Sinds 1990 verricht het Researchcentrum voor Onderwijs en Arbeidsmarkt (ROA) in opdracht van het College van Bestuur periodiek onderzoek naar de arbeidsmarktintrede van alumni van Maastricht University. Vanaf 1998 wordt daarnaast ook periodiek onderzoek gedaan naar de ontwikkeling van hun loopbanen. Dit alumnionderzoek (Arbeidsmarktscanner Maastricht University) bestaat jaarlijks uit drie metingen waarbij de alumni die $\mathrm{I}^{1} / 2,5^{1 / 2}$ en $\mathrm{IO}^{1} / 2$ jaar eerder zijn afgestudeerd via internet een digitale vragenlijst ontvangen.

De projectleiding van het onderzoek onder alumni van Maastricht University berust vanaf 2009 bij Christoph Meng van het ROA. Het onderzoek wordt uitgevoerd in samenwerking met het Studentenservicecentrum (SSC) van Maastricht University en DESAN Research Solutions. Het ROA is verantwoordelijk voor de methodologische en inhoudelijke aspecten van het project, de rapportages en het beheer van de onderzoeksgegevens. Bij het Studentenservicecentrum van Maastricht University is aan het onderzoek meegewerkt door Daniëlle Townsend-Prevoo. Bij DESAN Research Solutions hebben Monique van Alphen en Han van Dongen aan het onderzoek meegewerkt. Vanuit Maastricht University wordt het onderzoek begeleid door een klankbordgroep, bestaande uit H. van Berkel, P. Breuls, J. de Jong, A. van der Lugt, R. Meeuwissen, A. Rosenbach, D. Townsend-Prevoo en R. Wolleswinkel. De rapportage is samengesteld door Gerla van Breugel, Christoph Meng en Ger Ramaekers en de opmaak is verzorgd door Esther Soudant, allen werkzaam bij het ROA. 



\section{Samenvatting}

In dit rapport worden resultaten gepresenteerd van de in 2008 en 2009 uitgevoerde metingen onder alumni van Maastricht University. Deze betreffen drie momenten tijdens de loopbaan, namelijk $\mathrm{I}^{1} \frac{1}{2}, 5^{1 / 2}$ en IO $1 / 2$ jaar na afstuderen.

\section{Ontwikkeling van de loopbaan}

Aan de hand van de in 2008 en 2009 uitgevoerde metingen is in hoofdstuk 2 een beeld geschetst van de arbeidsmarktintrede (meting na $\mathrm{I}^{1} / 2$ jaar), de eerste fase van de loopbaan (meting na $5^{1 / 2}$ jaar) en het verdere verloop van de loopbaan (meting na IO $1 / 2$ jaar) van Maastrichtse alumni. Naar voren komt dat verreweg de meeste alumni die een jaar, vijf jaar of tien jaar geleden zijn afgestudeerd betaald werk hebben, variërend van $87 \%$ een jaar na afstuderen tot $91 \%$ tien jaar na afstuderen. De helft van de alumni die een jaar geleden zijn afgestudeerd heeft een vaste baan. Dit aandeel neemt toe tot driekwart van de afgestudeerden van vijf jaar terug en zelf $9 \mathrm{I} \%$ van de afgestudeerden van tien jaar geleden.

De overgrote meerderheid van de onderzochte alumni heeft een baan die qua niveau en richting past bij de gevolgde opleiding, en waarin de eigen capaciteiten in sterke mate kunnen worden benut. Alumni van Maastricht University gaan gaandeweg de loopbaan meer verdienen en komen naarmate de carrière vordert steeds vaker in leidinggevende posities terecht (ruim $40 \%$ van de $\mathrm{t}+\mathrm{IO}$ cohorten).

Gezien het bovenstaande is het niet verwonderlijk dat tussen de $70 \%$ en $80 \%$ van de onderzochte cohorten tevreden is met de huidige functie. Met het klimmen der jaren wordt wel iets vaker getwijfeld aan de juistheid van de gekozen studierichting. De keuze voor Maastricht University als universiteit blijft echter onbetwist.

\section{Reactie op een economische slechte periode}

In hoofdstuk 3 is nagegaan hoe de arbeidsmarktintrede van Maastrichtse alumni heeft gereageerd op de economisch slechte jaren 200I-2005. Gebleken is dat deze conjunctureel slechte periode geen duidelijk effect heeft gehad op de mate waarin afgestudeerden zich terugtrekken van de reguliere arbeidsmarkt, geïndiceerd door het aandeel dat voor zichzelf begint of besluit de arbeidsmarktintrede uit te stellen door verder onderwijs te gaan volgen. 
Voor de aanbieders op de arbeidsmarkt heeft de economisch slechte periode 200I2005 echter wel negatieve gevolgen gehad, en wel voor hun kans op werk, de zekerheid van hun werk, het niveau van hun werk en hun beloning: afgestudeerden die in economisch minder goede tijden hun opleiding afronden, hebben meer moeite om werk te vinden en vinden minder vaak werk dat bij hun opleidingsniveau past. Bovendien moeten zij zich, in vergelijking met afgestudeerden die zich in economisch goede jaren op de arbeidsmarkt aanbieden, vaker tevreden stellen met relatief minder goede arbeidsvoorwaarden (minder baanzekerheid en stagnerende beloning). Overigens lijken de nadelige gevolgen van een start op de arbeidsmarkt onder moeilijke conjuncturele omstandigheden al na een vijftal jaren te zijn weggeëbd.

\section{Crisisbeschermende factoren}

In hoofdstuk 4 is ingegaan op onderwijsgerelateerde (zowel op opleidingsniveau als op het niveau van de individuele afgestudeerde) factoren die de overgang van universiteit naar arbeidsmarkt in economische slechte tijden kunnen vergemakkelijken. Voor een succesvolle arbeidsmarktintrede dienen afgestudeerden (dus ook die van Maastricht University) een combinatie van een hoog niveau van vakspecifieke competenties en academische competenties te bezitten. Het probleemgestuurd onderwijs (PGO) van Maastricht University biedt daarvoor een uitermate geschikte leeromgeving. Afgestudeerden van probleemgestuurd onderwijs hebben namelijk een hoger niveau aan academische competenties dan afgestudeerden van niet-activerende leeromgevingen, zonder dat hierbij een trade-off met het aanleren van vakspecifieke competenties ontstaat.

Naast de PGO leeromgeving speelt vooral relevante werkervaring (zij het door een reguliere betaalde functie naast de studie, zij het door stage) een belangrijke rol in de arbeidsmarktintrede. Deze factoren bieden zelfs een toegevoegde bescherming in tijden van economisch mindere jaren. Overigens verhoogt relevante werkervaring het niveau van academische en vakspecifieke competenties, en heeft daarmee ook indirect een positief effect op de overgang van de universiteit naar de arbeidmarkt. 


\section{Summary}

This report presents results from the surveys held in 2008 and 2009 among alumni of Maastricht University. These surveys relate to three moments during their career, namely $\mathrm{I}^{1 / 2}(\mathrm{t}+\mathrm{I}), 5^{1 / 2}(\mathrm{t}+5)$ and $\mathrm{IO} \frac{1}{2}(\mathrm{t}+\mathrm{IO})$ years after graduation.

\section{Development of the career}

On the basis of the 2008/2009 surveys, chapter 2 outlines the entrance on the labour market (survey after $\mathrm{I}^{1 / 2}$ year), the first stage in the career (survey after $5^{1 / 2}$ year) and the further development of the career (survey after IO $1 / 2$ year) of Maastricht alumni. By far most of the alumni, graduated I1/2 year, $5^{1 / 2}$ year or IO $1 / 2$ year ago, have paid employment, varying from $87 \% \mathrm{I}^{1 / 2}$ year after graduation to $9 \mathrm{I} \% \mathrm{IO} \frac{1 / 2}{2}$ years after graduation. Half of the paid working alumni who graduated $\mathrm{I}^{1 / 2}$ year ago have a steady job. This increases up to three quart of the paid working alumni who graduated $5^{1 / 2}$ years ago and even $9 \mathrm{I} \%$ of the paid working alumni who graduated IO $1 / 2$ years ago.

The vast majority of the paid working alumni have jobs that match the level and direction of their education, and wherein their capacities can to a very large extent be put to use. As their career progresses, the income of Maastricht University graduates increases just like their entrance in supervisory jobs (well over $40 \%$ of the $\mathrm{t}+\mathrm{IO}$ cohorts).

In view of the above, it is not surprisingly that between $70 \%$ and $80 \%$ of the cohorts is (very) satisfied with their current job. However, as their career progresses they more often start having doubts about the correctness of their choice of study. Their choice for Maastricht University as the right university however remains unquestioned.

\section{Reaction to an economic crisis}

In chapter 3 it was ascertained how the entrance on the labour market of Maastricht alumni has reacted on the economic bad years of 200I-2005. It turned out that this period did not affect the extent to which graduates withdrew from the regular labour market, indicated by the share that went for self-employment or the share who postponed entry to the labour market through pursuing further education.

For graduates who did not withdrew from the regular labour market, the economic bad years of 200I-2005 however did have negative consequences for their chance of 
work, job security, job level and wage: students graduating in economic bad years experienced more difficulties in finding a job, and less often found jobs that match their educational level. In addition, they had more often to content themselves with less good terms of employment (less job security and stagnating wages) compared to students graduating in economic good years. It should be noticed that the negative consequences of a labour market entrance during economic bad years already will die out after five years.

\section{Protective factors against crises}

Chapter 4 looked into education-related factors (both on the level of education and on the level of the individual graduate) that might facilitate the transition from university to the labour market in economic bad years. For a successful labour market entrance, graduates (including those from Maastricht University) should possess high levels of both academic and discipline-specific competences. The problem-based learning (PBL) at Maastricht University offers an extremely well-suited activating learning environment for that. Graduates from a PBL learning environment acquire namely a higher level of academic competences than graduates from less-activating learning environments, without that a trade-off occurs with the acquisition of disciplinespecific competences.

Besides PBL also relevant work experience (in the form of a regular job beside the study or an internship) plays an important role in facilitating labour market entrance, even during economic bad years. It should be noticed that relevant work experience also raises the levels of both academic and discipline-specific competences and hence indirectly facilitates the transition from university to the labour market. 


\section{Inleiding}

\subsection{Arbeidsmarktscanner Maastricht University}

Het Researchcentrum voor Onderwijs en Arbeidsmarkt (ROA) verricht sinds 1990 in samenwerking met het Studentenservicecentrum van Maastricht University (UM) periodiek onderzoek onder alumni van Maastricht University. Dit onderzoeksproject, de Arbeidsmarktscanner Maastricht University, wordt uitgevoerd in opdracht van het College van Bestuur van Maastricht University. Het betreft een langlopend project dat informatie verschaft over de gevolgde opleiding, arbeidsmarktintrede en het verdere verloop van de loopbaan van Maastrichtse alumni. Hiertoe worden alumni ongeveer $\mathrm{I}^{1 / 2}$ jaar $(\mathrm{t}+\mathrm{I})$, $5^{1 / 2}$ jaar $(\mathrm{t}+5)$ en $\mathrm{IO}^{1 / 2} / 2$ jaar $(\mathrm{t}+\mathrm{IO})$ na afstuderen benaderd. De alumni ontvangen een digitale vragenlijst die via internet wordt afgenomen. ${ }^{\mathrm{I}}$ In de vragenlijst wordt gevraagd naar de afgesloten opleiding, de arbeidsmarktintrede, het verdere verloop van de loopbaan, verworven en vereiste competenties en de opleiding aan Maastricht University achteraf bezien. De drie vragenlijsten die jaarlijks worden afgenomen verschillen van elkaar, afhankelijk van het tijdstip van de meting. Voor alumni die na $I^{1} \frac{1}{2}$ jaar een vragenlijst ontvangen, staat de arbeidsmarktintrede centraal. Met deze meting wordt meer inzicht verkregen in de overgang van Maastricht University naar de arbeidsmarkt. In de vragenlijsten $5^{1 / 2}$ en IO $1 / 2$ jaar na afstuderen staat het loopbaanverloop centraal. Over de resultaten van de metingen wordt tweejaarlijks verslag gedaan in een rapport van het ROA: Loopbanen na Maastricht University. Het laatste rapport is uitgekomen in 2008, en had betrekking op de in 2006 en 2007 uitgevoerde metingen. In 2008 en 2009 hebben weer nieuwe metingen plaatsgevonden onder alumni van Maastricht University. In het voorjaar van 2008 en 2009 (voor alumni $5^{1 / 2}$ en IO $1 / 2$ jaar na afstuderen) en eind 2008 en 2009 (voor alumni I $1 \frac{1}{2}$ jaar na afstuderen). In deze rapportage wordt hiervan verslag gedaan. In bijlage I van dit rapport wordt ingegaan op de respons van deze metingen.

I. Het toenemend internationale karakter van Maastricht University leidt ertoe dat steeds meer buitenlandse studenten een opleiding volgen aan Maastricht University. Deze buitenlandse studenten (met uitzondering van Belgische) worden benaderd met een Engelse versie van de vragenlijst. 
In 2008 en 2009 uitgevoerde metingen onder alumni van Maastricht University:

\begin{tabular}{|c|c|c|}
\hline Meetmoment & Soort meting & Afstudeercohort \\
\hline \multicolumn{3}{|l|}{2008} \\
\hline - Voorjaar & $t+10$ & 1996-1997 \\
\hline - Voorjaar & $t+5$ & $2001-2002$ \\
\hline - Najaar & $t+1$ & 2006-2007 \\
\hline \multicolumn{3}{|l|}{2009} \\
\hline - Voorjaar & $t+10$ & 1997-1998 \\
\hline - Voorjaar & $t+5$ & $2002-2003$ \\
\hline - Najaar & $t+1^{*}$ & $2007-2008$ \\
\hline
\end{tabular}

Over de resultaten van de jaarlijkse t+I meting wordt nog op andere wijze gerapporteerd. De afzonderlijke faculteiten ${ }^{2}$ ontvangen jaarlijks elk een faculteitsrapportage. Deze rapportage aan de faculteiten vindt op twee manieren plaats.

- In de eerste plaats in de vorm van een gedrukte faculteitsrapportage. Deze bevat de belangrijkste resultaten van de betreffende faculteit, geordend naar de verschillende accreditatieaspecten, en per opleiding een aantal gegevens over de evenwichtigheid van het studieprogramma en een aantal kerngegevens over vervolgopleiding, functie en competenties. Deze gedrukte rapportage heeft betrekking op afgestudeerden van voltijdse opleidingen.

- In de tweede plaats in de vorm van een digitale versie. Deze bevat naast de al genoemde onderdelen van de gedrukte faculteitsrapportage alle overige informatie uit de WO-Monitor. In dit digitale rapport kan door het aanklikken van links verder worden ingezoomd op de indicatoren die voor accreditatie van belang zijn. Het digitale rapport is beschikbaar in twee versies: een voor afgestudeerden van voltijdse opleidingen en indien van toepassing een voor afgestudeerden van deeltijdopleidingen.

Voor het College van Bestuur wordt jaarlijks een overzichtsrapport gemaakt waarin de belangrijkste resultaten per faculteit staan vermeld.

Verder wordt ingegaan op (incidentele) verzoeken om informatie vanuit diverse geledingen van Maastricht University. Daarbij gaat het om bijdragen aan voorlichting-

2. Maastricht University herbergt de volgende faculteiten/Schools: Faculteit der Cultuur- en Maatschappijwetenschappen (FdCMW), Faculteit der Psychologie (FdP), Faculteit der Rechtsgeleerdheid (FdR), Maastricht ICT Competence Centre (MICC), Faculty of Health, Medicine and Life Sciences (bestaande uit de vroegere Faculteit der Geneeskunde (FdG) en Faculteit der Gezondheidswetenschappen (FdGW)) en Maastricht University School of Business and Economics (MUSBE). 
dagen, onderwijsverslagen, voorlichtingsbrochures, symposia en onderwijsmiddagen. Bovendien worden de gegevens gebruikt voor specifieke rapportages, scripties, dissertaties en paperbijdragen aan wetenschappelijke congressen.

Deze gegevens uit de t+I metingen vormen de input voor het berekenen van door het ROA ontwikkelde kwaliteitsindicatoren voor het hoger onderwijs. Deze zijn te vinden op de website van het ROA: www.roa.n

\subsection{Leeswijzer}

Het rapport is als volgt opgebouwd. Om te beginnen worden in hoofdstuk 2 de meest actuele cijfers van de in 2008 en 2009 uitgevoerde $t+I, t+5$ en $t+10$ metingen gepresenteerd. Dit hoofdstuk is vooral gericht op de vraag hoe het de Maastrichtse alumni in de verschillende fasen van hun loopbaan thans vergaat. Op basis van deze cross sectionele data wordt eerst ingegaan op de maatschappelijke positie in 2008 c.q. 2009. Voor degenen met betaald werk wordt specifiek ingegaan op de aard van het dienstverband. Vervolgens worden de banen beschreven aan de hand van de allocatie op de arbeidsmarkt (aansluiting opleiding-werk, benutting van capaciteiten). Daarna volgen de opbrengsten op de arbeidsmarkt in de zin van werkzekerheid, beloning, leidinggeven, carrièremogelijkheden en ondernemerschap. Vervolgens wordt ingegaan op de tevredenheid van de alumni over hun huidige werk en de gevolgde opleiding aan Maastricht University. Tot slot worden de belangrijkste bevindingen samengevat.

In de volgende twee hoofdstukken wordt ingegaan op de korte termijn effecten van de economische crisis voor afgestudeerden van Maastricht University. Daarnaast staan we stil bij onderwijsgerelateerde factoren die de afgestudeerden bij hun overgang naar de arbeidsmarkt additionele bescherming bieden in tijden van economische malaise. Hiervoor maken we gebruik van de mogelijkheden die het trendbestand van de Arbeidsmarktscanner Maastricht University van de jaren 1998 (cohort 1996/1997) tot en met 2008 (cohort 2006/2007) biedt.

In hoofdstuk 3 staan we stil bij de vraag in hoeverre (al dan niet conjunctureel bepaalde) veranderingen in de vraag-aanbod verhoudingen op de arbeidsmarkt voor recent afgestudeerde academici het arbeidsmarktsucces van afgestudeerden van Maastricht University in de jaren 1998 tot en met 2008 heeft beïnvloed. Hiermee kunnen de korte ( $\mathrm{I}, 5$ jaar) termijneffecten van een economische crisis in kaart gebracht worden. Nadat we de korte termijn effecten van een economische malaise besproken hebben, staan we aan het einde van dit hoofdstuk kort stil bij de vraag in hoeverre een moeizame start op de arbeidsmarkt gevolgen heeft voor de middellange termijn (de eerste vijf à zes jaar op de arbeidsmarkt). 
In aansluiting op hoofdstuk 3 komt tot slot in hoofdstuk 4 de vraag aan de orde welke onderwijsgerelateerde (zowel op opleidingsniveau als op het niveau van de individuele afgestudeerden) factoren de overgang van universiteit naar arbeidsmarkt vergemakkelijken. Hierbij kan gedacht worden aan o.a. bepaalde competenties (bijvoorbeeld generieke versus vakspecifieke competenties) en het al dan niet verplicht lopen van een stage. Aangezien Maastricht University, zeker op universiteitsniveau, een uitzonderlijke leeromgeving biedt, is het ook interessant om te zien of de leeromgeving aan Maastricht University: a) deze factoren stimuleert en b) een toegevoegde bescherming biedt aan afgestudeerden in tijden van economische crisis. 


\section{Actuele arbeidsmarktpositie van Maastrichtse alumni: resultaten metingen 2008-2009}

Dit hoofdstuk presenteert een aantal kernresultaten van alle enquêtes die het ROA in 2008 en 2009 heeft gehouden onder alumni van Maastricht University. ${ }^{3}$ Dit hoofdstuk bespreekt dus een aantal aspecten van de arbeidsmarktpositie in 2008 of 2009 van drie verschillende groepen alumni van de UM. Het gaat om alumni die hun opleiding ruim Io jaar, ruim 5 jaar of ruim een jaar geleden hebben afgerond. Om tot voldoende celvulling in de tabellen van dit hoofdstuk te komen, worden de afstudeercohorten 1996-1997 en 1997-1998 samen genomen voor de presentatie van de resultaten van de in 2008 en 2009 uitgevoerde $t+10$ metingen. Om dezelfde reden zijn de resultaten van de in 2008 en 2009 uitgevoerde $t+5$ metingen gebaseerd op samenvoeging van de afstudeercohorten 200I-2002 en 2002-2003. De t+I meting daarentegen is gebaseerd op één afstudeercohort, 20062007, omdat op het moment van schrijven van deze rapportage de resultaten van het afstudeercohort 2007-2008 nog niet beschikbaar zijn.

744 afgestudeerden van afstudeercohort 2006/2007 hebben de vragenlijst beantwoord. De meerderheid van hen is vrouw (61\%) en de gemiddelde leeftijd is 28,4 jaar. Bijna een derde van deze respondenten is afgestudeerd als gezondheidswetenschapper. De $\mathrm{t}+5$ metingen zijn door 1335 afgestudeerden uit de afstudeercohorten 200I-2002 en 2002-2003 ingevuld. Hun gemiddelde leeftijd is 3I,6 jaar en $63 \%$ van hen is vrouw. Ongeveer $30 \%$ van de respondenten heeft een economische studie gevolgd en een zelfde percentage is afkomstig van de studie gezondheidswetenschappen. De 'oudste' twee afstudeercohorten die samen de t+IO metingen vormen (1996-1997 en 1997-1998) omvatten 844 respondenten, voor $60 \%$ bestaande uit vrouwen en met een gemiddelde leeftijd van 37,3 jaar. Ook in deze cohorten zijn de economen en de gezondheidswetenschappers ruim vertegenwoordigd (29\%, respectievelijk $33 \%)$.

De diverse componenten die een beeld geven van de huidige arbeidsmarktpositie van UM-alumni komen als volgt aan bod. In de eerste paragraaf van dit hoofdstuk wordt ingegaan op de huidige maatschappelijke positie van de UM-alumni (betaald werkend, studerend, etc.) zoals die door henzelf is omschreven. Van

3. Ten tijde van het schrijven van dit rapport waren de resultaten van de eind 2009 uitgevoerde $\mathrm{t}+\mathrm{I}$ meting onder afstudeercohort 2007-2008 nog niet beschikbaar. 
degenen die betaald werk hebben, worden de kenmerken van het dienstverband beschreven. Vervolgens wordt in paragraaf 2.2 beschreven in hoeverre de UMalumni terecht zijn gekomen in banen die bij hen passen qua opleidingsniveau, -richting, capaciteiten, en dergelijke. De derde paragraaf laat zien wat de studie de alumni heeft opgeleverd in termen van werkzekerheid, salaris, carrièremogelijkheden, etc. Paragraaf 2.4 gaat in op de tevredenheid van de alumni over het werk dat ze hebben en de opleiding die ze hebben gevolgd. In paragraaf 2.5 tot slot worden de belangrijkste bevindingen samengevat.

\subsection{Huidige maatschappelijke positie en soort dienstverband}

Hoe zien UM-alumni zichzelf ruim een jaar, vijf jaar of tien jaar na hun afstuderen? Wat is volgens henzelf hun hoofdactiviteit? Tabel 2.I geeft een beeld van de maatschappelijke positie van de alumni zoals zij dat karakteriseren. Verreweg het grootste deel van de alumni ziet zichzelf als 'betaald werkend', en dit percentage stijgt licht naarmate de alumni langer geleden zijn afgestudeerd. Onder de alumni uit de $\mathrm{t}+\mathrm{I}$ metingen studeert $8 \%$ voornamelijk nog, maar dit percentage is aanzienlijk lager bij de alumni van de $t+5$ metingen ( $2 \%)$. Van de afgestudeerden van ruim tien jaar geleden ziet niemand zich meer als 'student'. Een nadere analyse van de categorie 'anders' bij de afgestudeerden van vijf en tien jaar geleden laat zien dat een deel van deze alumni zorgtaken als voornaamste dagbesteding heeft. Dit zijn overigens uitsluitend alumna. Onder de afgestudeerden van vijf jaar geleden gaat het om I\% van alle alumni en bij de afgestudeerden van tien jaar geleden gaat het om $2,5 \%$ van de gehele groep.

Tussen de afgestudeerden van de diverse faculteiten bestaat echter wel een aantal verschillen; vooral binnen de groep meest recent afgestudeerden. In die groep zien we dat de economen, gezondheidswetenschappers, juristen en zeker de medici voornamelijk betaald werk verrichten. Bij de psychologen, en vooral de cultuuren maatschappijwetenschappers is dit percentage (veel) lager. De psychologen die niet aan het werk zijn studeren nog, terwijl onder de cultuur- en maatschappijwetenschappers een deel van de niet-betaald werkenden studeert en een deel op zoek is naar een baan. Deze verschillen zijn in latere jaren vrijwel verdwenen. ${ }^{4}$

Nadere analyse van de maatschappelijke positie tussen mannen en vrouwen laat zien dat deze aanvankelijk nauwelijks verschilt. Pas bij de afgestudeerden die ruim tien jaar geleden zijn afgestudeerd zien we verschillende levenspaden ontstaan: terwijl 95\% van de mannen nog altijd betaald werk verricht, is dit percentage

4. Het percentage van $7 \mathbf{I} \%$ voor betaald werk onder de cultuur- en maatschappijwetenschappers is wel degelijk afwijkend van de andere faculteiten in de cohorten 'na tien jaar'. Deze groep is echter dusdanig beperkt van omvang dat de uitkomsten voor deze groep met voorzichtigheid moeten worden betracht. 
onder de vrouwen gedaald naar $88 \% .4 \%$ van de vrouwen richt zich op zorgtaken, $\mathrm{I} \%$ is werkzoekend en $7 \%$ doet iets anders.

Tabel 2.1

Maatschappelijke positie in 2008/2009, naar afstudeercohort (\%)

$\begin{array}{lrrrrrrr} & \text { FdCMW } & \text { FdG } & \text { FdGW } & \text { FdP } & \text { FdR } & \text { MUSBE } & \text { Totaal } \\ & & & & & & & \\ \text { Na één jaar (cohort 2006-2007) } & 65 & 95 & 89 & 80 & 90 & 89 & 87 \\ \text { betaald werk } & 10 & 3 & 3 & 0 & 5 & 3 & 4 \\ \text { werkzoekend } & 20 & 3 & 6 & 20 & 4 & 7 & 8 \\ \text { studie } & 5 & 0 & 1 & 0 & 1 & 1 & 1 \\ \text { anders } & & & & & & & \end{array}$

$\begin{array}{lrrrrrrr}\text { Na vijf jaar (cohort 2001-2002/2002-2003) } & & & & & & \\ \text { betaald werk } & 88 & 83 & 91 & 85 & 89 & 93 & 89 \\ \text { werkzoekend } & 0 & 0 & 2 & 3 & 1 & 1 & 1 \\ \text { studie } & 2 & 2 & 2 & 2 & 1 & 1 & 2 \\ \text { anders } & 10 & 15 & 5 & 10 & 10 & 5 & 8\end{array}$

$\begin{array}{lrrrrrrr}\text { Na tien jaar (cohort 1996-1997/1997-1998) } & & & & & & \\ \text { betaald werk } & 71 & 95 & 90 & X & 90 & 95 & 91 \\ \text { werkzoekend } & 4 & 1 & 0 & X & 1 & 0 & 0 \\ \text { studie } & 0 & 0 & 0 & X & 0 & 0 & 0 \\ \text { anders } & 25 & 4 & 9 & X & 9 & 5 & 8\end{array}$

Bron: ROA

Van de alumni met 'betaald werk' uit tabel 2.I wordt in tabel 2.2 getoond wat voor soort dienstverband zij hebben. De meeste alumni (gemiddeld ruim $80 \%$ ) werken al vanaf het begin van hun loopbaan in loondienst, en dit blijft gemiddeld genomen vrijwel ongewijzigd in latere fases van hun carrière.

Alumni die vrijwel meteen na hun afstuderen als AIO of OIO aan de slag gaan, vinden we vooral bij de medici (I7\%) en de psychologen (28\%). Van de alumni die vijf jaar geleden zijn afgestudeerd, is zelfs een kwart van alle medici werkzaam als $\mathrm{AIO} / \mathrm{OIO}$, terwijl dit aandeel bij de psychologen dan is afgenomen naar $7 \%$.

Alumni beginnen doorgaans voor zichzelf als ze al enige jaren werkervaring hebben. De hoogste percentages zelfstandigen vinden we dan ook onder alumni die tien jaar geleden zijn afgestudeerd. Het gaat dan met name om medici (28\%),

5. In de tabel ontbreken de gegevens voor de t+Io metingen van de psychologen. De faculteit psychologie bestaat namelijk pas sinds I995 waardoor de t+IO metingen (afstudeercohorten 1996-I997 en I9971998) nog geen afgestudeerde psychologen bevatten. Dit geldt voor alle tabellen in dit hoofdstuk. 
cultuur- en maatschappijwetenschappers (20\%) en juristen (I4\%) die voor zichzelf zijn begonnen.

Tabel 2.2

Soort dienstverband in 2008/2009, naar afstudeercohort (\%)

$\begin{array}{lrrrrrrr} & \text { FdCMW } & \text { FdG } & \text { FdGW } & \text { FdP } & \text { FdR } & \text { MUSBE } & \text { Totaal } \\ \text { Na één jaar (cohort 2006-2007) } & & & & & & & \\ \text { loondienst } & 81 & 81 & 87 & 66 & 91 & 86 & 83 \\ \text { Al0/0I0 } & 7 & 17 & 8 & 28 & 2 & 8 & 12 \\ \text { zelfstandige/freelancer } & 2 & 0 & 2 & 0 & 4 & 3 & 2 \\ \text { anders } & 9 & 2 & 3 & 7 & 3 & 3 & 3\end{array}$

$\begin{array}{lrrrrrrr}\text { Na vijf jaar (cohort 2001-2002/2002-2003) } & & & & & & & \\ \text { loondienst } & 81 & 57 & 90 & 86 & 87 & 91 & 85 \\ \text { AlO/0I0 } & 9 & 25 & 7 & 7 & 2 & 1 & 7 \\ \text { zelfstandige/freelancer } & 7 & 9 & 2 & 6 & 8 & 6 & 6 \\ \text { anders } & 2 & 9 & 1 & 1 & 3 & 2 & 3\end{array}$

$\begin{array}{lrrrrrrr}\text { Na tien jaar (cohort 1996-1997/1997-1998) } & & & & & & & \\ \text { loondienst } & 75 & 68 & 93 & X & 85 & 89 & 86 \\ \text { Al0/0I0 } & 0 & 1 & 0 & X & 0 & 0 & 0 \\ \text { zelfstandige/freelancer } & 20 & 28 & 5 & X & 14 & 8 & 12 \\ \text { anders } & 5 & 4 & 2 & X & 1 & 3 & 2 \\ \text { X Geen of te weinig cases } & & & & & & & \\ \text { Bron: ROA } & & & & & & \end{array}$

\subsection{Allocatie op de arbeidsmarkt (waar is men terecht gekomen?)}

In de vorige paragraaf hebben we gezien dat de meeste UM-alumni al snel na hun afstuderen betaald werk verrichten. In dat opzicht worden de alumni dus grotendeels in het arbeidsproces benut. De vraag is echter of dit ook zo optimaal mogelijk gebeurd. Daarom kijken we in deze paragraaf naar de aansluiting van het werk op de gevolgde opleiding en naar de mate van benutting van de capaciteiten van de alumni.

De aansluiting opleiding-werk wordt formeel bepaald door te vragen naar de eisen die de werkgever aan de huidige functie heeft gesteld zowel qua opleidingsniveau als qua opleidingsrichting. Uit tabel 2.3. blijkt dat ongeveer driekwart van de betaald werkende alumni die een jaar geleden zijn afgestudeerd in een functie op wo-niveau werkzaam is. Dat aandeel stijgt in latere jaren nog door naar rond de $80 \%$. Net na de studie zijn het vooral de medici en de psychologen 
die op universitair niveau werken en die dat blijven doen naarmate hun loopbaan zich ontwikkelt. De gezondheidswetenschappers en juristen stappen daarentegen vaker op een iets lager niveau in om vervolgens alsnog door te groeien naar een functie op wo-niveau.

Tabel 2.3

Werk op WO-niveau in 2008/2009, naar afstudeercohort (\%)

$\begin{array}{lcccccccc} & \text { FdCMW } & \text { FdG } & \text { FdGW } & \text { FdP } & \text { FdR } & \text { MUSBE } & \text { Totaal } \\ & & & & & & & \\ \text { Na één jaar (cohort 2006-2007) } & 81 & 100 & 56 & 93 & 69 & 72 & 74 \\ \text { Na vijf jaar (cohort 2001-2002/2002-2003) } & 71 & 100 & 79 & 88 & 82 & 83 & 84 \\ \text { Na tien jaar (cohort 1996-1997/1997-1998) } & 80 & 98 & 73 & X & 82 & 78 & 80 \\ \text { X Geen of te weinig cases } & & & & & & & \\ \text { Bron: ROA } & & & & & & & \end{array}$

Ongeveer driekwart van alle betaald werkende alumni heeft een baan die aansluit bij hun studierichting gedurende de eerste tien jaar van hun loopbaan (tabel 2.4). De medici werken, door hun zeer specialistische en beroepsgerichte opleiding, bijna allemaal binnen hun domein. De cultuur- en maatschappijwetenschappers zijn daarentegen van meet af aan vaker buiten hun domein werkzaam, en dat aandeel stijgt naarmate de loopbaan van deze alumni vordert. De economen en juristen zitten hier ongeveer tussenin, met minstens twee derde van de alumni die in het betreffende vakgebied of een verwant vakgebied werkzaam zijn. Gezondheidswetenschappers werken naarmate hun carrière vordert ook iets vaker in een ander domein, maar dit aandeel loopt op tot slechts een kwart van de gezondheidswetenschappers die tien jaar geleden zijn afgestudeerd.

Tabel 2.4

Werk in eigen/verwante opleidingsrichting in 2008/2009, naar afstudeercohort (\%)

\begin{tabular}{lccccccccc} 
& FdCMW & FdG & FdGW & FdP & FdR & MUSBE & Totaal \\
\hline Na één jaar (cohort 2006-2007) & 54 & 93 & 82 & 90 & 67 & 73 & 78 \\
Na vijf jaar (cohort 2001-2002/2002-2003) & 49 & 95 & 79 & 80 & 73 & 77 & 78 \\
Na tien jaar (cohort 1996-1997/1997-1998) & 45 & 95 & 74 & $X$ & 68 & 67 & 73 \\
$\begin{array}{l}\text { X Geen of te weinig cases } \\
\text { Bron: ROA }\end{array}$ & & & & & & & & \\
\end{tabular}

De meer informele aansluiting opleiding-werk is gebaseerd op een globale inschatting van deze aansluiting door de alumni zelf. De betaald werkende alumni konden op een 4-puntschaal (slecht, matig, voldoende, goed) aangeven in welke mate hun functie aansluit op hun opleiding aan de UM. Door de bank genomen sluit de huidige baan van 4 van de 5 UM-alumni voldoende tot goed aan op de gevolgde studie, ongeacht hoe lang geleden de alumni zijn afgestudeerd (zie tabel 2.5). Net als in de tabellen 2.3 en 2.4 over de formele aansluiting opleiding-werk 
vinden de medici ook de informele aansluiting het vaakst voldoende tot goed, terwijl de cultuur- en maatschappijwetenschappers dit het minst vaak vinden. Ook de percentages per faculteit zijn op dit aspect behoorlijk stabiel over de afstudeercohorten heen.

Tabel 2.5

Voldoende/goede aansluiting opleiding/werk in 2008/2009, naar afstudeercohort (\%)

\begin{tabular}{lccccccc} 
& FdCMW & FdG & FdGW & FdP & FdR & MUSBE & Totaal \\
& & & & & & & \\
Na één jaar (cohort 2006-2007) & 68 & 96 & 77 & 72 & 72 & 82 & 80 \\
\hline Na vijf jaar (cohort 2001-2002/2002-2003) & 73 & 98 & 82 & 77 & 83 & 83 & 84 \\
Na tien jaar (cohort 1996-1997/1997-1998) & $X$ & 94 & 80 & $X$ & 77 & 84 & 83 \\
$\begin{array}{l}\text { X Geen of te weinig cases } \\
\text { Bron: ROA }\end{array}$ & & & & & & & \\
\end{tabular}

Tijdens hun studie verwerven en verbeteren de UM-alumni diverse capaciteiten. Worden deze capaciteiten ook voldoende benut? Tabel 2.6 laat zien dat de capaciteiten van gemiddeld $7 \mathrm{I} \%$ van de alumni die een jaar geleden zijn afgestudeerd in sterke mate worden benut. Dit percentage loopt voor de oudere cohorten zelfs op tot $80 \%$. Tussen de faculteiten zijn er echter nogal wat verschillen, vooral in het cohort met de meest recente afgestudeerden. Slechts iets meer dan de helft van de recent afgestudeerde cultuur- en maatschappijwetenschappers vindt dat de eigen capaciteiten in voldoende mate worden benut. Bij de gezondheidswetenschappers en de juristen is dit ongeveer tweederde, terwijl van de economen en psychologen een goede $70 \%$ tevreden is over de benutting van de eigen capaciteiten. Niet geheel onverwacht worden de capaciteiten van de medici naar eigen zeggen het vaakst benut. Immers, van deze groep alumni sloot hun baan het vakst aan op de opleiding. Opvallend is dat per faculteit het aandeel alumni dat vindt dat de capaciteiten in sterke mate worden benut tussen het cohort $t+I$ en $t+5$ toeneemt, maar niet tussen cohort $\mathrm{t}+5$ en $\mathrm{t}+\mathrm{IO}$. Wellicht dat de alumni die tien jaar geleden zijn afgestudeerd inmiddels vaker zijn 'uitgegroeid' in hun huidige functie. Ze kennen het 'trucje' inmiddels wel en zijn toe aan andere, meer uitdagende werkzaamheden.

\section{Tabel 2.6}

Sterke benutting van capaciteiten* in 2008/2009, naar afstudeercohort (\%)

$\begin{array}{lcccccc} & \text { FdCMW } & \text { FdG } & \text { FdGW } & \text { FdP } & \text { FdR } & \text { MUSBE } \\ & & & & & & \\ \text { Notaal }\end{array}$




\subsection{Opbrengsten van de opleiding op de arbeidsmarkt (extern rendement)}

UM-alumni komen, volgens de resultaten gepresenteerd in paragraaf 2.2, vooral terecht in betaalde functies. In deze paragraaf gaan we om te beginnen dieper in op de aard en omvang van deze functies. Hoeveel werkzekerheid hebben de alumni binnen hun werk, hoeveel uur per week werken ze, wat verdienen ze er mee? Vervolgens kijken we naar de toekomst door een beeld te schetsen van het leidinggevend karakter van de functies en de carrièreperspectieven.

Gemiddeld heeft iets meer dan de helft van de alumni in 2008 of 2009 een vaste baan ruim een jaar na afstuderen (zie tabel 2.7). Bij de alumni die al langer afgestudeerd zijn, neemt dit percentage rap toe: tot 91\% van de afgestudeerden van ruim tien jaar geleden. Opvallend is wel dat de verschillen tussen de faculteiten vooral onder de afgestudeerden $t+I$ en $t+5$ groot zijn. Zo heeft bijvoorbeeld $70 \%$ van de economen uit de $\mathrm{t}+\mathrm{I}$ meting een vaste baan, onder medici is dit een derde en bij de psychologen slechts een kwart. Eerder gepresenteerde resultaten doen vermoeden dat dit te maken heeft met het feit dat AIO's, OIO's en artsen in opleiding per definitie een tijdelijke aanstelling krijgen voor de duur van de opleiding of het promotietraject. Deze functies komen vooral onder medici en psychologen veel voor (zie tabel 2.2), en onder hen is de werkzekerheid in de beginjaren van de loopbaan dan ook het laagst (zie tabel 2.7). De beschreven verschillen in werkzekerheid die aan het begin van de carrières van UM-alumni tussen de faculteiten bestaan, verdwijnen grotendeels in de loop der jaren: binnen de t+Io groep zien we slechts nog kleine verschillen in werkzekerheid.

Tabel 2.7

Werkzekerheid in 2008/2009, naar afstudeercohort (\% vaste aanstellingen*)

$\begin{array}{lccccccc} & \text { FdCMW } & \text { FdG } & \text { FdGW } & \text { FdP } & \text { FdR } & \text { MUSBE } & \text { Totaal } \\ & & & & & & & \\ \text { Na één jaar (cohort 2006-2007) } & 56 & 33 & 59 & 26 & 55 & 70 & 53 \\ \text { Na vijf jaar (cohort 2001-2002/2002-2003) } & 65 & 51 & 71 & 64 & 88 & 89 & 76 \\ \text { Na tien jaar (cohort 1996-1997/1997-1998) } & \mathrm{X} & 87 & 90 & \mathrm{X} & 96 & 93 & 91 \\ \text { * Inclusief in proeftijd voor vaste baan } & & & & & & & \\ \begin{array}{l}\text { X Geen of te weinig cases } \\ \text { Bron: ROA }\end{array} & & & & & & & \end{array}$

Tabel 2.8 laat zien dat UM-alumni, zeker in het begin van hun loopbaan, vaak fulltime werken ${ }^{6}: 79 \%$ van de alumni die een jaar geleden zijn afgestudeerd en $77 \%$ van degenen die vijf jaar geleden zijn afgestudeerd werkt fulltime. Bij de groep afgestudeerden $\mathrm{t}+\mathrm{IO}$ is dit aandeel gedaald naar tweederde van de alumni. Uit diverse studies is bekend dat vrouwen over het algemeen minder vaak fulltime werken dan mannen. Nadere analyse van deze drie afstudeercohorten laat zien

6. Fulltime wordt in dit onderzoek gedefinieerd als 33 uur per week of meer. 
dat deze verschillen zich ook onder UM-alumni manifesteren vanaf het begin van hun loopbaan. Van de alumna die ruim een jaar geleden zijn afgestudeerd, werkte in 2008 of 2009 driekwart fulltime, terwijl dit percentage onder hun mannelijke tegenhangers 90\% betrof. In latere jaren worden de verschillen alleen maar groter: tweederde van de vrouwen die vijf jaar geleden zijn afgestudeerd werkt fulltime tegenover $92 \%$ van de mannen, en tien jaar na afstuderen werkt nog niet eens de helft van de vrouwelijke afgestudeerden fulltime tegenover nog steeds $92 \%$ van de mannen.

Tabel 2.8

Fulltime werk in 2008/2009, naar afstudeercohort (\%)

\begin{tabular}{lcccccccc} 
& FdCMW & FdG & FdGW & FdP & FdR & MUSBE & Totaal \\
\hline Na één jaar (cohort 2006-2007) & 74 & 96 & 62 & 59 & 89 & 92 & 79 \\
Na vijf jaar (cohort 2001-2002/2002-2003) & 72 & 83 & 58 & 60 & 87 & 94 & 77 \\
Na tien jaar (cohort 1996-1997/1997-1998) & 60 & 66 & 48 & $X$ & 65 & 83 & 65 \\
$\begin{array}{l}\text { X Geen of te weinig cases } \\
\text { Bron: ROA }\end{array}$ & & & & & & &
\end{tabular}

Als het gaat om het rendement van een gevolgde opleiding, uitgedrukt in 'harde' euro's, is het zinvol om naar de beloning te kijken van de afgestudeerden in de verschillende cohorten. In tabel 2.9 is zowel het bruto maandloon als het bruto uurloon weergegeven. Het bruto maandloon is namelijk afhankelijk van het aantal gewerkte uren, en dit aantal varieert nogal tussen zowel de alumni per cohort als de alumni per faculteit (zie tabel 2.8). Om die reden is het bruto uurloon een betere maatstaf om het financiële rendement van de diverse cohorten en faculteiten met elkaar te vergelijken. Het bruto uurloon is berekend op basis van het door de alumni opgegeven bruto maandloon en het aantal gewerkte uren.

De financiële opbrengsten voor de UM-afgestudeerden nemen in de loop der jaren gestaag toe: UM-alumni verdienen in 2008/2009 ongeveer $€ 2.500$ per maand als ze iets meer dan een jaar afgestudeerd zijn, terwijl hun voorgangers die vijf jaar eerder zijn afgestudeerd al $€ 3.400$ verdienen. De afgestudeerden van ruim tien jaar geleden verdienen zelfs nog $€$ I.00o meer per maand. De bruto uurlonen zijn tussen de afgestudeerden van een jaar geleden en die van tien jaar geleden ook bijna verdubbeld, en wel van $€ 15,87$ naar $€ 28,85$.

De grootverdieners qua bruto maandloon vinden we, zeker bij de recent afgestudeerden, vooral onder economen en medici en daarna onder de juristen en gezondheidswetenschappers. Over het algemeen zijn dit ook de studies waarvan het grootste deel van de alumni fulltime werkt, uitgezonderd de gezondheidswetenschappers (zie tabel 2.8). De gezondheidswetenschappers danken hun relatief hoog bruto maandloon dan ook aan hun relatief hoog bruto uurloon (het 
hoogste van alle faculteiten voor alumni die een jaar geleden afgestudeerd zijn). Het relatief hoge bruto uurloon van gezondheidswetenschappers houdt verband met het relatief hoge aandeel van deeltijdstudenten bij GW, die vaak al een baan hebben tijdens hun studie aan de UM. Zo bestaat 38\% van de gezondheidswetenschappers (afstudeercohort 2006-2007) uit deeltijdstudenten en had 19\% van de betaald werkende gezondheidswetenschappers van dit cohort de huidige baan al vóór 2006. Voor de totale UM bedragen de percentages respectievelijk I4\% (deeltijd) en 9\% (baan vóór 2006). Het bruto salaris van de economen (in uurloon en maandloon gemeten) ontwikkelt zich na de goede start ook snel in de vijf jaar die er op volgen, maar onder de alumni die tien jaar geleden afgestudeerd zijn, verdienen de medici inmiddels het meest per uur en per maand. Zij hebben in de io jaar na afstuderen dan ook het meest/langst middels post-doctorale opleidingen geïnvesteerd in hun menselijk kapitaal.

\section{Tabel 2.9}

Mediaan? bruto maandloon en mediaan bruto uurloon in 2008/2009, naar afstudeercohort ( $€$ )

\begin{tabular}{|lrrrrrrrr|} 
& FdCMW & FdG & FdGW & FdP & FdR & MUSBE & Totaal \\
\hline Na één jaar (cohort 2006-2007) & & & & & & & \\
& 1.961 & 2.917 & 2.500 & 2.000 & 2.593 & 2.800 & 2.500 \\
& 12,69 & 16,03 & 17,10 & 13,27 & 15,69 & 16,57 & 15,87 \\
\hline Na vijf jaar (cohort 2001-2002/2002-2003) & 2.900 & 3.484 & 3.000 & 3.000 & 3.575 & 4.000 & 3.400 \\
& 17,67 & 18,17 & 20,60 & 19,64 & 22,43 & 23,72 & 21,63 \\
\hline Na tien jaar (cohort 1996-1997/1997-1998) & $X$ & 5.652 & 3.800 & $X$ & 4.300 & 5.400 & 4.400 \\
& $X$ & 36,12 & 25,96 & $X$ & 28,85 & 32,77 & 28,85
\end{tabular}

$X$ Geen of te weinig cases

Bron: ROA

Leidinggeven is een aspect van de functie dat doorgaans pas in een later stadium van de carrière een rol gaat spelen. Zo ook bij de UM-alumni: gemiddeld geeft ongeveer één op de vijf recent afgestudeerden in 2008 of 2009 leiding aan anderen, terwijl $46 \%$ van de afgestudeerden van ruim tien jaar geleden een leidinggevende functie heeft (tabel 2.IO). Opvallend is dat een derde van de cultuur- en maatschappijwetenschappers die een jaar geleden zijn afgestudeerd al leiding geeft. Het aantal medici en psychologen dat leiding geeft in het begin van hun loopbaan is juist laag, waarschijnlijk vanwege de al eerder genoemde promotie- en opleidingstrajecten die vooral deze alumni vaak volgen. Naarmate de loopbaan vordert zijn

7. In deze tabel wordt het mediaan bruto maandloon en bruto uurloon weergeven i.p.v. het gemiddelde bruto maandloon en bruto uurloon. Enkele combinaties van cohort-faculteit bevatten immers een beperkt aantal observaties. In deze combinaties leiden extreme waarnemingen al snel tot vertekeningen van het gemiddelde loon. De mediaan kent dit nadeel niet. Vandaar dat hieraan de voorkeur wordt gegeven in deze tabel. 
het vooral de medici, economen en juristen die in leidinggevende posities terecht komen.

Tabel 2.10

Werkzaam in een leidinggevende functie in $2008 / 2009$, naar afstudeercohort (\%)

\begin{tabular}{lcccccccc} 
& FdCMW & FdG & FdGW & FdP & FdR & MUSBE & Totaal \\
& & & & & & & \\
Na één jaar (cohort 2006-2007) & 33 & 15 & 17 & 14 & 20 & 21 & 19 \\
\hline Na vijf jaar (cohort 2001-2002/2002-2003) & 14 & 20 & 23 & 29 & 27 & 42 & 29 \\
Na tien jaar (cohort 1996-1997/1997-1998) & 15 & 57 & 37 & $X$ & 43 & 55 & 46 \\
X Geen of te weinig cases & & & & & & & \\
Bron: ROA & & & & & & &
\end{tabular}

UM-alumni verdienen dus, zeker in de loop van hun carrière, een niet onverdienstelijk salaris en een deel van hen heeft een leidinggevende functie. Maar hoe zit het met de toekomst? Kunnen deze alumni zich blijven ontwikkelen in hun huidige functie? Tabel 2.II laat zien dat de alumni vooral aan het begin van hun carrière (heel) veel ontwikkelmogelijkheden hebben in hun functie, en dat dit daarna gemiddeld iets afneemt. Echter, van degenen die tien jaar geleden zijn afgestudeerd, is nog altijd 6I\% van mening dat de huidige functie veel tot heel veel carrièremogelijkheden biedt. Vooral economen en medici zien, zeker in de eerste I- 5 jaar, veel ontwikkelmogelijkheden. Na vijf jaar worden de verschillen tussen de alumni van de verschillende faculteiten kleiner.

Tabel 2.11

(Heel) veel carrièremogelijkheden* in 2008/2009, naar afstudeercohort (\%)

\begin{tabular}{|c|c|c|c|c|c|c|c|}
\hline & $\mathrm{FdCMW}$ & FdG & FdGW & FdP & $\mathrm{FdR}$ & MUSBE & Totaal \\
\hline Na één jaar (cohort 2006-2007) & 57 & 87 & 60 & 72 & 61 & 80 & 69 \\
\hline Na vijf jaar (cohort 2001-2002/2002-2003) & 60 & 82 & 55 & 60 & 61 & 80 & 67 \\
\hline Na tien jaar (cohort 1996-1997/1997-1998) & $x$ & 61 & 50 & $x$ & 62 & 73 & 61 \\
\hline
\end{tabular}

\subsection{Tevredenheid over werk en opleiding}

Een ruime meerderheid van de UM-alumni die betaald werk hebben, is in functies terecht gekomen waarin ze zich verder kunnen ontwikkelen. Ook over andere aspecten van de functie die tot nu toe in dit hoofdstuk zijn besproken, zijn veel UM-alumni positief, al verschilt dit soms per afstudeercohort en iets vaker tussen de diverse faculteiten. Een lakmoesproef voor de algehele tevredenheid met de huidige functie vormt echter de vraag "Hoe tevreden bent $\mathrm{u}$ met uw huidige 
functie?" Welnu, tabel 2.I2 laat zien dat een ruime meerderheid van $70 \%$ van het $\mathrm{t}+\mathrm{I}$ cohort (zeer) tevreden is met de huidige functie. Van de cohorten afgestudeerden die al wat langer op de arbeidsmarkt actief zijn $(t+5$ en $t+10)$ is zelfs ongeveer $80 \%$ tevreden tot zeer tevreden met de huidige baan. Deze percentages zijn in lijn met die in de vorige tabellen.

Verder zien we in tabel 2.12 dat de medici het meest tevreden zijn met hun baan, terwijl de juristen en de psychologen het minst tevreden zijn. Echter, de verschillen met bijvoorbeeld de cultuur- en maatschappijwetenschappers en de gezondheidswetenschappers zijn klein. Sowieso worden de verschillen tussen de alumni van de diverse faculteiten kleiner naarmate de alumni langer geleden afgezwaaid zijn.

Tabel 2.12

Tevreden* met functie in 2008/2009, naar afstudeercohort (\%)

\begin{tabular}{|lcccccccc|} 
& FdCMW & FdG & FdGW & FdP & FdR & MUSBE & Totaal \\
\hline Na één jaar (cohort 2006-2007) & 68 & 89 & 67 & 62 & 63 & 77 & 72 \\
\hline Na vijf jaar (cohort 2001-2002/2002-2003) & 80 & 90 & 78 & 83 & 73 & 78 & 79 \\
\hline Na tien jaar (cohort 1996-1997/1997-1998) & $X$ & 91 & 78 & $X$ & 83 & 80 & 81
\end{tabular}

* Antwoord 4 of 5 op 5 -puntschaal ( 1 ='zeer ontevreden'; 5 ='zeer tevreden')

$X$ Geen of te weinig cases

Bron: ROA

Echter, de lakmoesproef voor de algehele tevredenheid over de genoten opleiding vormt de vraag "Zou u achteraf gezien, de door u gevolgde opleiding aan de UM opnieuw kiezen?”. Tabel 2.I3 laat zien hoe de UM-alumni van de drie cohorten hier op hebben geantwoord. $72 \%$ tot $80 \%$ van de afgestudeerden zou weer precies dezelfde keuze maken. I6\% tot $22 \%$ van de afgestudeerden zou achteraf gezien liever een andere studie hebben gevolgd. Slechts een paar procent van de alumni is wel tevreden over de studiekeuze, maar niet over de keuze van de UM als universiteit.

De medici, zeker die van de latere afstudeercohorten, zijn het meest tevreden met hun studiekeuze: $84 \%$ tot $90 \%$ zou dezelfde opleiding kiezen aan de UM. Slechts een paar procent van hen zou achteraf liever iets anders zijn gaan studeren. Wel is het opvallend dat van het cohort $\mathrm{t}+\mathrm{I}$ één van de tien medici de studie liever aan een andere universiteit dan de UM zou hebben gevolgd. Ook een meerderheid van de gezondheidswetenschappers is tevreden over de studiekeuze. Toch zou een kwart (en van het $\mathrm{t}+5$ cohort zelfs $31 \%$ ) van hen, achteraf bezien, een andere studie hebben gekozen. 
Het overgrote deel van de economen en juristen kiest in tweede instantie ook weer voor dezelfde studie en voor de UM. Dit geldt zeker voor de economen die ruim een jaar geleden afgestudeerd zijn (89\%). Echter, naarmate de alumni van beide faculteiten hun alma mater langer geleden hebben achtergelaten, gaan ze meer twijfelen over de juistheid van hun studiekeuze. Zo zou één van de vijf economen die tien jaar geleden zijn afgestudeerd en één van de vier juristen van dezelfde afstudeerlichting nu een andere studie kiezen. Kort samengevat, gaandeweg hun carrière komen steeds meer alumni er achter dat ze achteraf gezien beter een andere studie hadden kunnen kiezen. Deze conclusie blijft overeind als voor de $\mathrm{t}+5$ en de $\mathrm{t}+\mathrm{IO}$ cohorten rekening wordt gehouden met wat zij bij hun $\mathrm{t}+\mathrm{I}$ meting hebben ingevuld. De conclusie lijkt dus gebaseerd te zijn op 'leeftijdeffecten (lengte van de loopbaan) en niet op eventuele periode-effecten (arbeidsmarktsituatie ten tijde van intrede) of cohort-effecten (specifieke kenmerken van het desbetreffende cohort). De keuze voor de UM als universiteit wordt door alumni echter nauwelijks als een 'foute' keuze bestempeld. Over alle afstudeercohorten en faculteiten heen, is overigens drie van de vier alumni tevreden over zowel de studiekeuze als de keuze van de UM als universiteit.

Tabel 2.13

Opleidingskeuze achteraf bezien in 2008/2009, naar afstudeercohort (\%)

$\begin{array}{lrrrrrrr} & \text { FdCMW } & \text { FdG } & \text { FdGW } & \text { FdP } & \text { FdR } & \text { MUSBE } & \text { Totaal } \\ \text { Na één jaar (cohort 2006-2007) } & & & & & & & \\ \text { dezelfde opleiding aan dezelfde universiteit } & 82 & 84 & 71 & 77 & 77 & 89 & 80 \\ \text { dezelfde opleiding aan een andere universiteit } & 3 & 10 & 3 & 3 & 5 & 2 & 4 \\ \text { andere opleiding } & 14 & 6 & 24 & 20 & 17 & 10 & 16 \\ \text { niet gaan studeren } & 1 & 0 & 1 & 0 & 1 & 0 & 1\end{array}$

$\begin{array}{lrrrrrrr}\text { Na vijf jaar (cohort 2001-2002/2002-2003) } & & & & & & \\ \text { dezelfde opleiding aan dezelfde universiteit } & 68 & 89 & 64 & 69 & 74 & 76 & 72 \\ \text { dezelfde opleiding aan een andere universiteit } & 0 & 7 & 5 & 14 & 7 & 4 & 6 \\ \text { andere opleiding } & 32 & 4 & 31 & 18 & 18 & 20 & 22 \\ \text { niet gaan studeren } & 0 & 0 & 0 & 0 & 1 & 1 & 0\end{array}$

$\begin{array}{lrrrrrrr}\text { Na tien jaar (cohort 1996-1997/1997-1998) } & & & & & & \\ \text { dezelfde opleiding aan dezelfde universiteit } & X & 90 & 70 & X & 72 & 77 & 75 \\ \text { dezelfde opleiding aan een andere universiteit } & X & 3 & 4 & X & 0 & 3 & 3 \\ \text { andere opleiding } & X & 8 & 25 & X & 27 & 20 & 22 \\ \text { niet gaan studeren } & X & 0 & 2 & X & 2 & 0 & 1 \\ \text { X Geen of te weinig cases } & & & & & & & \\ \text { Bron: } \mathrm{ROA} & \end{array}$




\subsection{Samenvatting en conclusies}

\section{Maatschappelijke positie:}

De metingen onder UM-alumni die in 2008 en 2009 plaats hebben gevonden, laten zien dat verreweg de meeste van deze alumni die een jaar, vijf jaar of tien jaar geleden zijn afgestudeerd betaald werk hebben: van $87 \%$ van de alumni die een jaar geleden zijn afgestudeerd tot $91 \%$ van degenen die tien jaar geleden zijn afgestudeerd. Deze betaalde arbeid wordt vooral in loondienst verricht. Echter, het aandeel zelfstandigen/freelanders neemt toe onder de 'oudere' cohorten, tot I2\% van de alumni die tien jaar geleden zijn afgestudeerd.

\section{Allocatie op de arbeidsmarkt:}

De grote meerderheid van de onderzochte afstudeercohorten heeft een baan die past bij de gevolgde opleiding qua niveau en qua richting. Een ruime meerderheid van de betaald werkende alumni heeft een functie die voldoende tot goed aansluit op de opleiding en waarin de eigen capaciteiten in sterke mate kunnen worden benut.

\section{Extern rendement:}

De helft van de alumni die een jaar geleden afgestudeerd zijn, heeft een vaste baan op de kop weten te tikken na het verlaten van de opleiding. Dit aandeel neemt toe tot driekwart van de afgestudeerden van vijf jaar terug en zelf $91 \%$ van de afgestudeerden van tien jaar geleden. Het aandeel fulltime werkenden neemt af naarmate de alumni langer geleden afgestudeerd zijn. Dit hangt waarschijnlijk samen met het groeiende aandeel vrouwen in de populatie UM-alumni. Zij werken naarmate de carriere vordert vaker in deeltijd in verband met de zorg voor de kinderen.

UM-alumni gaan gaandeweg de loopbaan meer verdienen en komen naarmate de carriere vordert steeds vaker in leidinggevende posities terecht (ruim $40 \%$ van de t+IO cohorten). De carrièremogelijkheden nemen daarentegen licht af in de loop der tijd.

\section{Tevredenheid:}

Tussen de $70 \%$ en $80 \%$ van alle cohorten is dan ook tevreden met de huidige functie. Met het klimmen der jaren wordt iets vaker getwijfeld aan de juistheid van de gekozen studie. De keuze voor de UM als universiteit blijft echter onbetwist. 



\section{Effect van macro-economische shocks op de arbeidsmarktintrede van Maastrichtse alumni}

\subsection{Inleiding}

Economische fluctuaties beïnvloeden in sterke mate de korte termijn arbeidsmarktkansen van recent afgestudeerden. De recessie in 2009 zal op deze regel geen uitzondering zijn. Zo valt te verwachten dat recent afgestudeerden meer moeite zullen hebben om werk te vinden, dat zij meer concurrentie zullen ondervinden van afgestudeerden van het hbo en dat zij eventueel vaker gedwongen worden om werk onder hun opleidingsniveau of buiten hun opleidingsrichting aan te nemen. Hoewel de precieze invloed van de 2009 recessie nog onduidelijk is op het moment van schrijven van deze rapportage, biedt de Arbeidsmarktscanner Maastricht University uitgebreide mogelijkheden om op basis van eerdere economisch moeilijke tijden verwachtingen voor de huidige generatie van afgestudeerden te formuleren. In dit hoofdstuk doen we dit door gebruik te maken van de mogelijkheden die de Arbeidsmarktscanner Maastricht University van de jaren 1998 (cohort 1996/1997) tot en met 2008 (cohort 2006/2007) biedt. Figuur 3.I laat zien dat het conjuncturele verloop in de periode 1995 tot en met 2008 een zwakke economische periode kent: de periode $200 \mathrm{I}-2005$, waarbij de economische groei in daljaar 2002 met $0,1 \%$ vrijwel tot stilstand was gekomen. Deze crisis van begin 2000 wordt in sterke mate toegeschreven aan het uiteenspatten van de internetbubble.

In dit hoofdstuk staan we eerst stil bij de vraag in hoeverre (al dan niet conjunctureel bepaalde) veranderingen in de vraag-aanbod verhoudingen op de arbeidsmarkt voor recent afgestudeerde academici het arbeidsmarktsucces van afgestudeerden van Maastricht University in de jaren 1995 tot en met 2008 hebben beïnvloed. Hiermee kunnen de korte (I, 5 jaar) termijn effecten van een economische crisis in kaart gebracht worden. De effecten die eerst aan bod komen zijn de kans op werk, de baanzekerheid, de aansluiting tussen opleiding en werk en de beloning.

Een economische malaise die gepaard kan gaan met een verminderde kans op werk, minder werkzekerheid, een lagere beloning alsmede een minder goede aansluiting tussen opleiding en werk dwingt recent afgestudeerden eventueel ook tot alternatieven die in eerste instantie niet in hun carrièreplanning voorkwamen. We zullen daarom ook stilstaan bij de vraag of in economisch mindere tijden de doorstroom 
naar vervolgonderwijs en het zelfstandig ondernemerschap als alternatieve opties interessanter worden.

Figuur 3.1

Economische groei (BBP) in Nederland, $1989-2008$

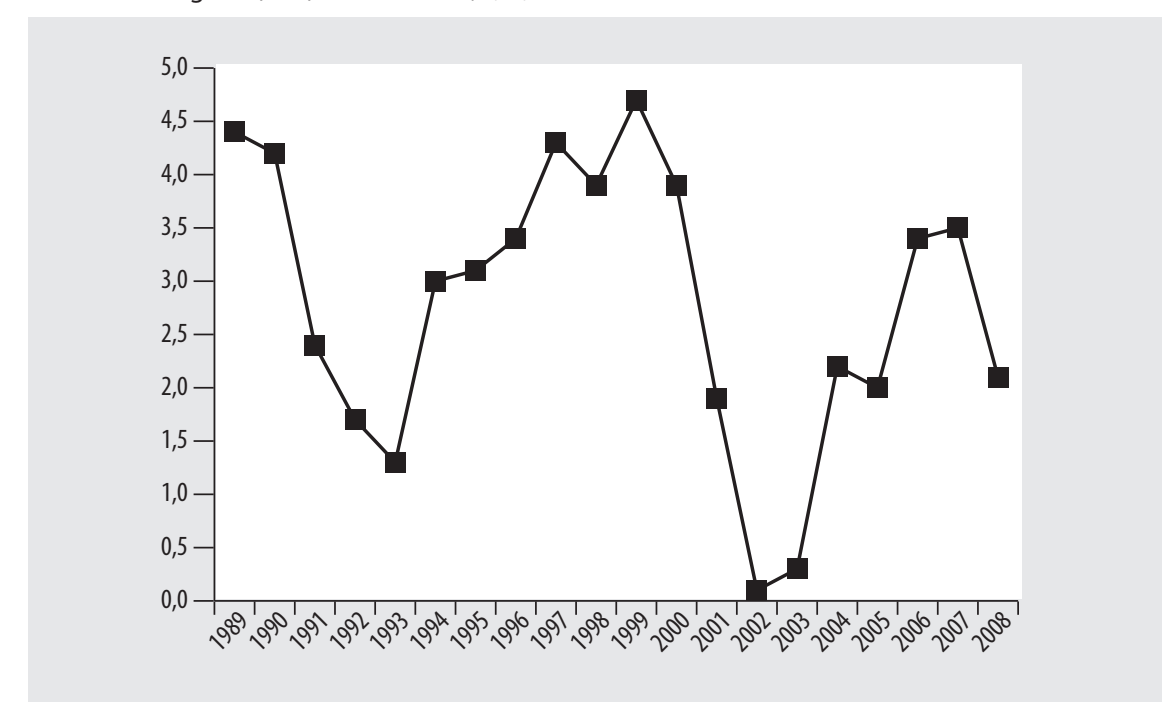

Nadat we de korte termijn effecten van een economische malaise uitgebreid besproken hebben, staan we aan het einde van dit hoofdstuk kort stil bij de vraag in welke mate een moeizame start op de arbeidsmarkt gevolgen voor de middellange termijn (de eerste vijf à zes jaar op de arbeidsmarkt) heeft. Tot slot worden in de laatste paragraaf de belangrijkste bevindingen van dit hoofdstuk samengevat.

\subsection{Kans op werk en baanzekerheid op korte termijn}

Een analyse van de korte termijn gevolgen van een economische malaise dient te starten bij de invloed hiervan op de kans op werk en de baanzekerheid die aan recent afgestudeerden wordt geboden. Immers, in economisch slechte tijden zullen werkgevers terughoudender zijn in het aannemen van nieuw personeel en zeker van personeel zonder (veel) arbeidsmarktervaring dat vaak eerst functie/bedrijfsspecifieke training nodig heeft. Economisch slechte tijden zijn vaak ook economisch onzekere tijden. Werkgevers die nieuw personeel aannemen, willen zich dan niet voor langere tijd binden, en het is dan ook te verwachten dat zij minder geneigd zijn om contracten voor onbepaalde tijd aan te gaan. 
De intredewerkloosheid, dat wil zeggen het aantal maanden dat men tussen het moment van afstuderen en de eerste baan werkzoekend is geweest, is een sterke indicator voor de kans op werk. Figuur 3.2 toont de conjunctuurgevoeligheid van de intredewerkloosheid. Was in de economisch sterke jaren (I998 tot begin 200I) minder dan IO\% van de afgestudeerden van de Maastricht University langer dan 3 werkzoekend, op het moment dat de economische groei sterk afnam steeg dit percentage tot bijna $20 \%$. Opvallend is dat de daling die in 2005 optrad zich in 2006 niet doorzet. Hier onderscheidt zich het beeld voor de afgestudeerden van de Maastricht University van het landelijke beeld. Reden hiervoor kan zijn dat de Nederlandse economie sneller uit het dal kwam dan de landen rond om Nederland die voor de afgestudeerden van Maastricht University een relatief belangrijkere rol hebben dan voor de gemiddelde afgestudeerde van een Nederlandse universiteit. Immers, bijna een op de drie afgestudeerden van Maastricht University vindt een baan in het buitenland terwijl dit onder alle afgestudeerden van de Nederlandse universiteiten nog geen IO\% is.

\section{Figuur 3.2}

Ontwikkeling intredewerkloosheid, 1998-2007 (\% meer dan 3 maanden werkzoekend)

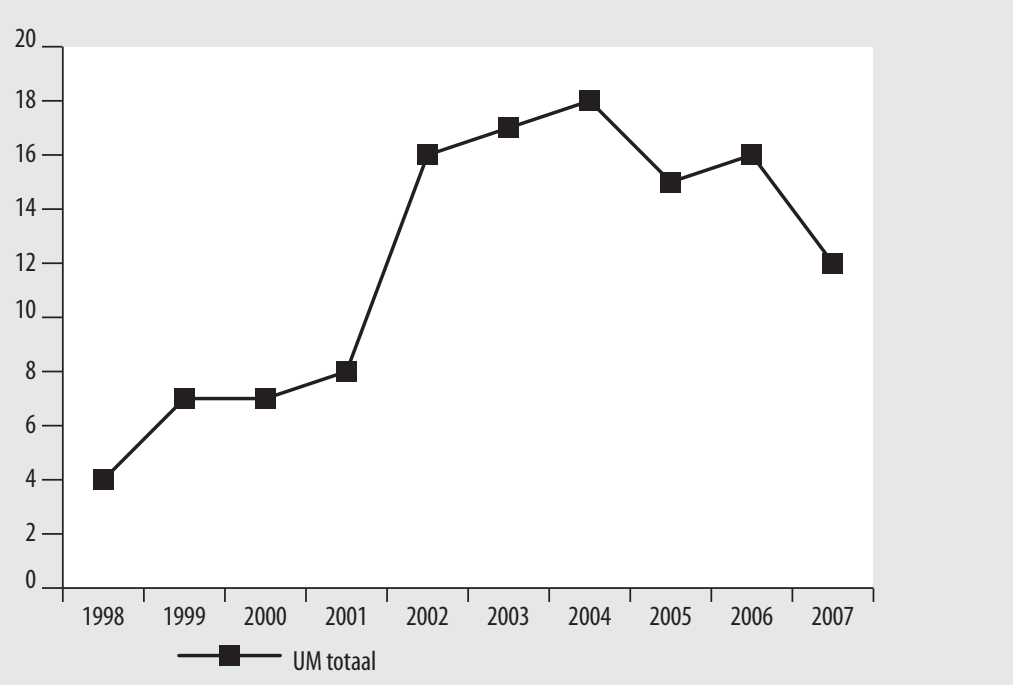

De conjunctuurgevoeligheid van de intredewerkloosheid zal mede afhankelijk zijn van de gevolgde opleiding. Tabel 3.I laat dan ook het verloop van de intredewerkloosheid per faculteit zien. Niet verrassend zien we dat de afgestudeerden van de Faculteit der Geneeskunde gemiddeld het kortst op zoek zijn naar een functie. Van hen is over de jaren heen gemiddeld minder dan $4 \%$ langer dan 3 maanden werkzoekend. Ook in tijden van crisis kennen deze afgestudeerden geen lange zoekduur. In tegenstelling hiermee loopt de zoekduur onder de afgestudeerden van de MUSBE snel hoog op in tijden van een crisis. Zij voelden de crisis die in 200 i begon dan ook als eerste. De 
afgestudeerden van de faculteit Gezondheidswetenschappen, de faculteit Psychologie en de faculteit Rechten bleken in eerste instantie nog enigszins beschermd tegen de neergang van de economie. Een jaar later dan de economen begon de arbeidsmarktsituatie voor de psychologen en de juristen aanzienlijk moeilijker te worden en in 2003 gold dit ook voor de afgestudeerden van de FdGW. Opvallend is dat op het moment dat de economie weer sterk begon te groeien (2007) de situatie voor de psychologen en de juristen niet direct verbeterde. Dit betekent dat zij, in tegenstelling tot de afgestudeerden van de MUSBE, op het moment dat in 2009 de recessie inzette al een relatief moeilijke arbeidsmarktintrede kenden.

Tabel 3.1

Intredewerkloosheid per faculteit, 1998-2007 (\% meer dan 3 maanden werkzoekend)

$\begin{array}{lrrrrrrrrrr} & 1998 & 1999 & 2000 & 2001 & 2002 & 2003 & 2004 & 2005 & 2006 & 2007 \\ \text { FdCMW } & X & X & 12,5 & X & X & 22,7 & 20,0 & 20,9 & 29,7 & 18,3 \\ \text { FdG } & 1,1 & 1,2 & 3,0 & 2,9 & 6,5 & 4,0 & 5,0 & 6,1 & 3,0 & 3,5 \\ \text { FdGW } & 4,5 & 4,0 & 7,4 & 8,3 & 12,6 & 16,1 & 18,1 & 15,4 & 13,1 & 9,3 \\ \text { FdP } & X & X & 11,8 & 9,1 & 19,4 & 26,4 & 17,5 & 20,3 & 21,1 & 30,6 \\ \text { FdR } & 3,8 & 13,4 & 8,3 & 5,0 & 14,1 & 17,4 & 27,0 & 12,9 & 18,8 & 19,1 \\ \text { MUSBE } & 3,5 & 8,1 & 6,7 & 15,1 & 23,0 & 20,7 & 19,6 & 18,3 & 18,7 & 10,6\end{array}$

X Geen (betrouwbaar) cijfer beschikbaar

In economisch slechte tijden neemt de baanzoekduur na het behalen van het diploma significant toe (figuur 3.2). Maar wat betekent dit voor de baanzekerheid van degenen die in crisistijden werk vinden? Figuur 3.3 toont dat de baanzekerheid van afgestudeerden van Maastricht University tot en met de crisisjaren 200I-2003 een stijgende trend laat zien. In de crisisjaren 2003-2005 daalt de baanzekerheid sterk, om vervolgens weer te stijgen. Kortom de ontwikkeling van de baanzekerheid lijkt tijdens de crisisperiode van 200I-2005 met enige vertraging te corresponderen met de economische ontwikkeling. We meten daarbij de baanzekerheid van de afgestudeerden aan de hand van het percentage vaste aanstellingen onder de betaald werkende afgestudeerden.

Tabel 3.2 laat zien dat de ontwikkeling van de baanzekerheid niet voor alle faculteiten gelijk verloopt:

- Bij de MUSBE laat de ontwikkeling van de baanzekerheid een fluctuerend verloop zien, zowel in goede tijden (I998-2000 en 2006-2008) als in slechte tijden (200I-2005). Bij de FdR neemt de baanzekerheid in de goede jaren 1998-2000 weliswaar toe, om vervolgens te fluctueren in zowel de slechte tijden (200I-2005) als de goede tijden (2006-2008).

- Bij de FdGW volgt de ontwikkeling van de baanzekerheid in grote lijnen de conjuncturele ontwikkeling: eerst een toename, gevolgd door een daling in de slechte jaren 2003-2005, waarna de baanzekerheid zich weer herstelt. Ook bij de FdCMW zien we relatief weinig baanzekerheid in de slechte jaren $200 \mathrm{I}$ en 
2005, gevolgd door een toename van de baanzekerheid als de conjunctuur zich weer herkrijgt.

- Bij de FdP volgt de ontwikkeling van de baanzekerheid de conjuncturele ontwikkeling niet.

Figuur 3.3

Ontwikkeling van het aandeel van vaste aanstellingen, 1998-2008 (\%)

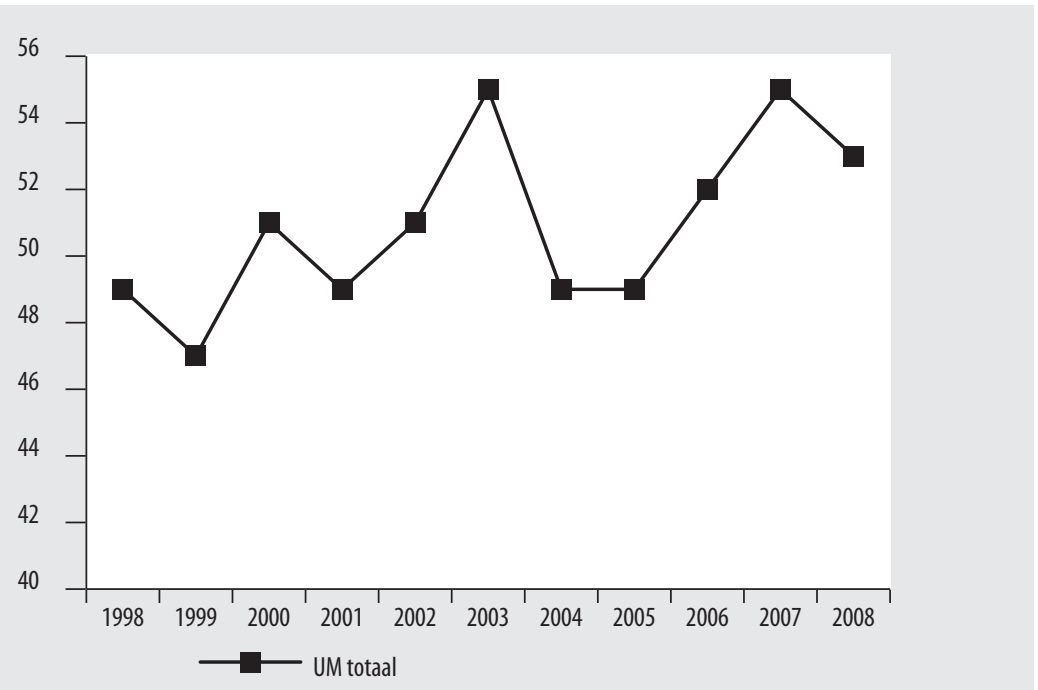

Tabel 3.2

Baanzekerheid per faculteit, 1998-2007 (\% vaste aanstellingen)

$\begin{array}{lrrrrrrrrrrr} & 1998 & 1999 & 2000 & 2001 & 2002 & 2003 & 2004 & 2005 & 2006 & 2007 & 2008 \\ \text { FdCMW } & X & X & X & 39 & X & X & X & 29 & 41 & 52 & 56 \\ \text { FdG } & 20 & 21 & 17 & 21 & 29 & 37 & 23 & 34 & 34 & 32 & 34 \\ \text { FdGW } & 49 & 47 & 48 & 54 & 56 & 50 & 44 & 43 & 48 & 49 & 59 \\ \text { FdP } & X & X & X & 24 & 30 & 28 & 33 & 33 & 27 & 29 & 26 \\ \text { FdR } & 49 & 52 & 55 & 40 & 48 & 54 & 52 & 40 & 50 & 46 & 56 \\ \text { MUSBE } & 71 & 66 & 74 & 75 & 69 & 75 & 66 & 70 & 75 & 74 & 70\end{array}$

$X$ Geen (betrouwbaar) cijfer beschikbaar.

Wat betekenen de bovenstaande analyses nu voor de situatie zoals die zich in Nederland voordoet in 2009? Bij de navolgende verwachtingen dient met een tweetal verschillen tussen de huidige crisis en de bestudeerde crisisperiode rekening te worden gehouden. Ten eerste is de economische terugval in 2009 aanzienlijk sterker dan de terugval in de crisisperiode 200I-2005. De verwachting is dat de baanzoekduur relatief snel zal oplopen, zeker onder de afgestudeerden van de meer conjunctuurgevoelige opleidingen (bijvoorbeeld economie). Daarnaast zal de economische recessie waarschijnlijk 
tot het minder snel aanbieden van een vaste aanstelling leiden, en zal het herstel in baanzekerheid bij recent afgestudeerden onderbroken worden. Het onderbreken van de verbetering in de baanzekerheid is in de meest recente meting (najaar 2008) al enigszins zichtbaar. Dit geldt niet voor het oplopen van de zoekduur. Immers, de zoekduur van de meting 2008 heeft betrekking op afgestudeerden van het cohort $2006 / 2007$ en dus op jongeren die zich gingen aanbieden op de arbeidsmarkt in 2007, dus ruim voor de crisis begon.

\subsection{Aansluiting opleiding-werk en beloning op korte termijn}

Vanuit maatschappelijk oogpunt is het van belang dat een universitaire afgestudeerde bij voorkeur een functie op universitair niveau vervult. Dat is immers de grondslag van het bestaan van verschillende onderwijssoorten. Ook vanuit individueel oogpunt mag worden verondersteld dat het voor een afgestudeerde van een universiteit belangrijk is een baan op universitair niveau te vinden, waar de in de opleiding opgedane competenties optimaal kunnen worden aangewend. Daarnaast kan, zeker op langere termijn, het 'use-it or lose-it' fenomeen een belangrijke rol spelen. Afgestudeerden die werkzaam zijn in een functie die niet of onvoldoende aansluit bij de gevolgde opleiding lopen het risico dat ze de in de studie opgebouwde capaciteiten niet voldoende kunnen benutten waardoor deze capaciteiten (deels) verloren gaan.

\section{Figuur 3.4}

Ontwikkeling van het aandeel van banen op universitair niveau, 1998-2008 (\%)

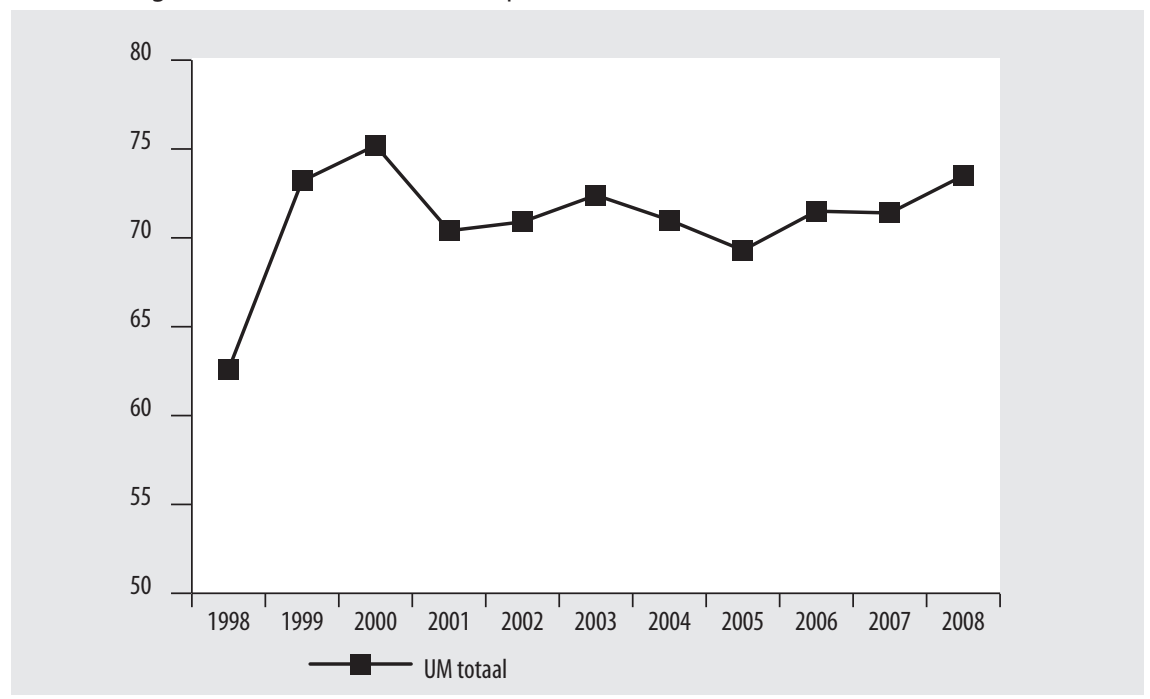


De aansluiting tussen de gevolgde opleiding en de huidige functie wordt hier eerst besproken aan de hand van de mate waarin de huidige functie aansluit bij het behaalde opleidingsniveau. Hierbij is gekeken naar de eisen die de werkgever stelt bij het vervullen van de vacature.

Figuur 3.4 toont voor de periode 1998-2008 de ontwikkeling van de aansluiting opleiding-werk naar niveau voor de afgestudeerden. Daarin is te zien dat na de piek in 2000 gedurende de crisisperiode, 200I-2005, relatief iets minder afgestudeerden een baan op hun eigen niveau hebben kunnen vinden. Echter ook in tijden van een crisis lijkt een ruime meerderheid een baan te vinden die qua niveau goed aansluit aan de gevolgde opleiding. Verder is te zien dat na de crisis het herstel onmiddellijk wordt ingezet. Het aandeel stijgt tot bijna weer driekwart (74\%) in 2008. Afgestudeerden vinden in een crisistijd dus iets minder eenvoudig een baan op het eigen opleidingsniveau.

Gemiddeld werkt daarmee zo'n 70\% van de afgestudeerden van Maastricht University in een functie die minimaal een diploma op WO niveau vereist. Kijken we naar eventuele verschillen tussen de afgestudeerden van de verschillende faculteiten (zie tabel 3.3), dan zien we een aantal belangrijke punten. Ten eerste, de afgestudeerden van de FdGW werken gemiddeld gezien vaker onder hun niveau dan afgestudeerden van de andere faculteiten. Dit houdt verband met het gegeven dat afgestudeerden van de FdGW relatief vaak vanuit een baan op HBO-niveau gezondheidswetenschappen in deeltijd hebben gestudeerd. Ten tweede, met uitzondering van de FdG (waar sprake is van een professionele vakdeelmarkt, met bijna een één op één relatie tussen opleiding en beroep) zien we dat in de economisch sterke jaren (1998-2000) het aandeel dat een functie op minimaal eigen niveau vond sterk toenam. Deze stijgende trend stopte in 200 I met het begin van de economisch minder goede jaren. Onder de afgestudeerde economen daalde het percentage dat een functie op eigen niveau vond zelfs met zo'n II\%-punt tussen 2000 en 200 I en duurde het tot 2007 tot er weer een stabielere situatie ontstond.

\section{Tabel 3.3}

Ontwikkeling van het aandeel van banen op universitair niveau, 1998-2008 (\% eigen/verwante richting vereist), per faculteit

\begin{tabular}{lrrrrrrrrrrr} 
& 1998 & 1999 & 2000 & 2001 & 2002 & 2003 & 2004 & 2005 & 2006 & 2007 & 2008 \\
\hline FDG & 100,0 & 98,9 & 100,0 & 98,4 & 100,0 & 100,0 & 100,0 & 99,0 & 100,0 & 100,0 & 100,0 \\
FDGW & 49,2 & 61,5 & 62,7 & 61,0 & 54,6 & 64,1 & 59,5 & 53,4 & 53,8 & 59,4 & 56,2 \\
FdP & $X$ & $X$ & $X$ & 87,9 & 78,0 & 71,4 & 85,7 & 75,5 & 82,5 & 69,6 & 93,1 \\
FdR & 69,2 & 80,9 & 77,6 & 77,3 & 83,5 & 85,3 & 69,9 & 78,1 & 83,2 & 74,7 & 68,8 \\
MUSBE & 57,1 & 65,9 & 72,3 & 60,8 & 63,6 & 64,5 & 69,3 & 62,4 & 65,7 & 73,1 & 71,1
\end{tabular}

$X$ Geen (betrouwbaar) cijfer beschikbaar. 
Naast de aansluiting opleiding-werk naar niveau is deze aansluiting ook geanalyseerd naar richting. Hierbij gaat het om de vraag of de afgestudeerde al dan niet binnen het 'eigen' beroependomein terechtkomt. Van het eigen beroependomein is sprake wanneer door de werkgever voor de desbetreffende functie (uitsluitend) de eigen opleidingsrichting of een daaraan verwante opleidingsrichting werd vereist. De interpretatie van de aansluiting tussen opleiding en werk naar richting is minder duidelijk dan bij de aansluiting naar niveau. Wanneer wordt verondersteld dat de aansluiting uitsluitend verloopt via vakgerelateerde competenties, zou kunnen worden beargumenteerd dat een functie waarvoor uitsluitend de eigen opleidingsrichting wordt vereist beter is dan een functie waarvoor de eigen of een verwante opleidingsrichting wordt vereist, die op zijn beurt weer beter is dan een functie waarvoor een geheel andere of geen specifieke opleidingsrichting wordt vereist. Echter, in steeds meer functies neemt het belang toe van algemene competenties die niet noodzakelijkerwijs op een bepaald vakgebied hoeven te liggen, zoals het kunnen oplossen van complexe problemen, het vermogen zich zelfstandig nieuwe kennis eigen te maken en het kunnen functioneren in een multidisciplinair team. Het valt op die manier te beargumenteren dat een functie waarvoor geen specifieke of een geheel andere opleidingsrichting wordt vereist niet per definitie slechter is dan een functie op vergelijkbaar niveau waarvoor (uitsluitend) de eigen of een daaraan verwante opleidingsrichting wordt vereist.

Figuur 3.5

Ontwikkeling van het aandeel van banen in eigen domein, 1998-2008 (\% eigen/verwante richting vereist)

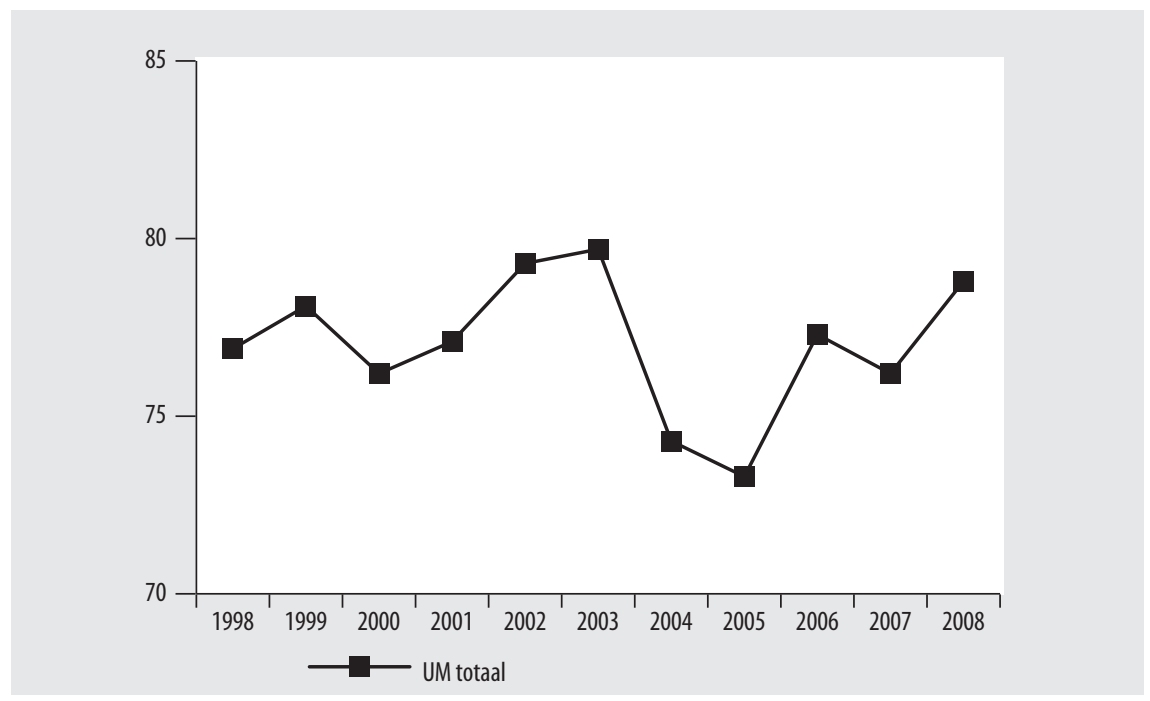

Over de beschouwde periode laat de mate van aansluiting qua opleidingsrichting een grillig verloop zien. Er is nauwelijks een systematisch verschil te zien tussen de mate 
van aansluiting qua opleidingsrichting tijdens de crisisperiode, 200I-2005, versus daar buiten (figuur 3.5). De aansluiting qua opleidingsrichting is derhalve in het algemeen minder conjunctuurgevoelig dan de aansluiting qua opleidingsniveau. Maar geldt dit ook als we naar de afgestudeerden van de verschillende faculteiten kijken. Tabel $3 \cdot 4$ laat zien dat de afgestudeerde economen wederom het snelst last van een economische crisis hebben. Het aandeel van hen dat een baan in het eigen domein vindt daalt van rond de 70\% in de jaren 1998-200I naar zo'n 63\% in 2002. Echter, in de jaren daarna stijgt het aandeel weer snel terug naar het oude niveau. Naast de economen zijn het vooral de juristen die in tijden van een crisis minder snel een functie in het eigen domein kunnen vinden. Tot slot laat tabel 3.4 nog een interessant, maar conjunctuuronafhankelijk, fenomeen zien onder de afgestudeerden van de FdG. Was tot 2004 (met uitzondering van 2003) bijna IO०\% van de afgestudeerden werkzaam in het eigen domein, sindsdien zien we dat zo'n 7 -IO\% van de afgestudeerden voor een functie buiten het eigen domein heeft gekozen.

Tabel 3.4

Ontwikkeling van het aandeel van banen in eigen domein, 1998-2008 (\% eigen/verwante richting vereist), per faculteit

$\begin{array}{lrrrrrrrrrrr} & 1998 & 1999 & 2000 & 2001 & 2002 & 2003 & 2004 & 2005 & 2006 & 2007 & 2008 \\ \text { FDG } & 100,0 & 100,0 & 98,8 & 100,0 & 98,7 & 91,8 & 97,2 & 93,0 & 93,2 & 90,2 & 92,4 \\ \text { FDGW } & 74,3 & 70,6 & 71,5 & 74,5 & 79,5 & 83,6 & 76,7 & 71,9 & 74,9 & 79,3 & 82,8 \\ \text { FdP } & X & X & X & 84,8 & 82,9 & 89,3 & 79,6 & 67,3 & 82,5 & 75,4 & 89,7 \\ \text { FdR } & 72,9 & 77,9 & 76,5 & 81,2 & 86,3 & 75,4 & 65,0 & 72,9 & 78,5 & 75,6 & 66,7 \\ \text { MUSBE } & 72,1 & 72,3 & 70,5 & 68,3 & 62,7 & 70,2 & 71,2 & 70,0 & 71,6 & 75,8 & 73,5\end{array}$

$X$ Geen (betrouwbaar) cijfer beschikbaar.

\section{Beloning}

Tot zover hebben de analyses laten zien dat de kans op werk, de baanzekerheid en het vinden van een qua niveau passende baan in economisch mindere tijden onder druk komen te staan. In wat volgt gaan we verder in op de functies die recent afgestudeerden vinden, en analyseren we in hoeverre de beloning in deze functies verschilt tussen economisch goede en economisch slechte tijden. We doen dit wederom voor de periode $1998-2008$.

In figuur 3.6 is de ontwikkeling van het bruto uurloon weergegeven vanaf I998 tot en met 2008. De cijfers in deze figuur hebben betrekking op de inkomsten uit de hoofdfunctie inclusief toeslagen. De gepresenteerde uurlonen betreffen de reële lonen: het zijn de nominale lonen gecorrigeerd op basis van de ontwikkeling van de consumentenprijsindices (inflatie) van het Centraal Bureau voor de Statistiek op basis van consumentenprijzen in 2008. 


\section{Figuur 3.6}

Ontwikkeling gemiddeld reëel bruto uurloon Maastricht University (in 2008 prijzen), 1998-2008 (€)

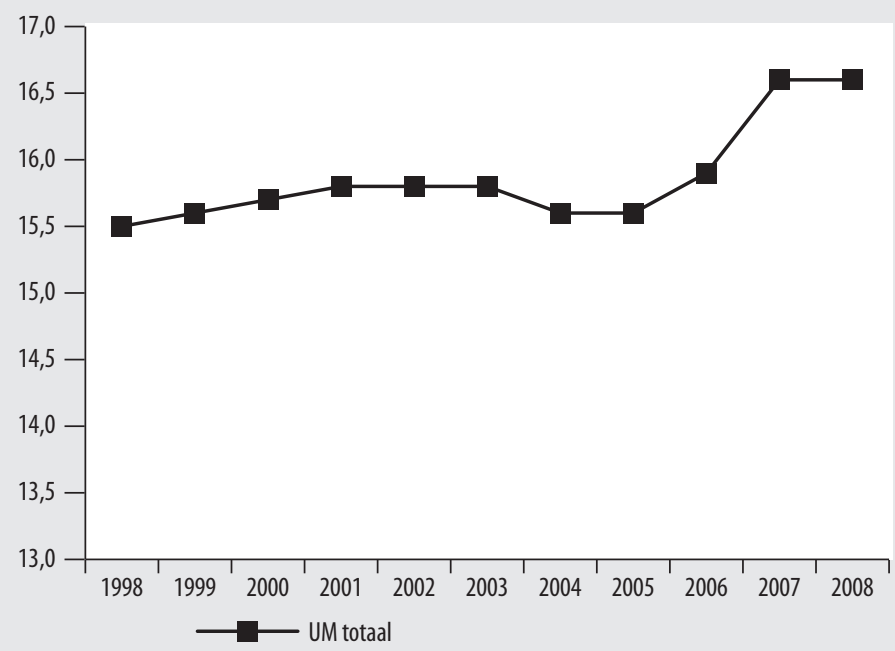

Uurloon afgerond op 10 Eurocent.

De ontwikkeling van het reële bruto uurloon laat zien dat de crisisperiode 200I-2005 een dempend effect op de loonontwikkeling heeft gehad. Vanaf 1998 tot en met $200 \mathrm{I}$ groeide het loon elk jaar gestaag. Echter, vanaf 200I stabiliseert het loon, gevolgd door een lichte daling die duurt tot en met het einde van deze crisis in 2005. Daarna neemt het reële bruto loon weer toe.

Figuur 3.7.A toont de ontwikkeling van het gemiddeld bruto uurloon voor de MUSBE en FdR, en figuur 3.7.B voor de medisch georiënteerde faculteiten van Maastricht University. Vanwege de vooralsnog kleine aantallen respondenten van de FdCMW en de FdP worden voor deze faculteiten hier geen cijfers gepresenteerd. De figuren laten zien dat de ontwikkeling van de reële lonen van afgestudeerden van de MUSBE en de FdR grosso modo de conjuncturele ontwikkeling volgt: een (lichte) toename in de goede jaren (1998-2000), gevolgd door een stabilisatie in de slechte jaren 200I-2005 en opnieuw een stijging in de goede jaren na 2005 . Bij de beloning van afgestudeerden van de FdGW zien we een dalende trend tot 2005, gevolgd door een toename als de conjunctuur zich na 2005 herstelt. Dit in tegenstelling tot de ontwikkeling van de beloning onder afgestudeerde basisartsen, waar de ontwikkeling van de reële lonen tot 2004 een stijgende trend laat zien, gevolgd door een dalende trend. 
Figuur 3.7.A

Ontwikkeling gemiddeld reëel bruto uurloon MUSBE en FdR (in 2008 prijzen), 1998-2008 (€)

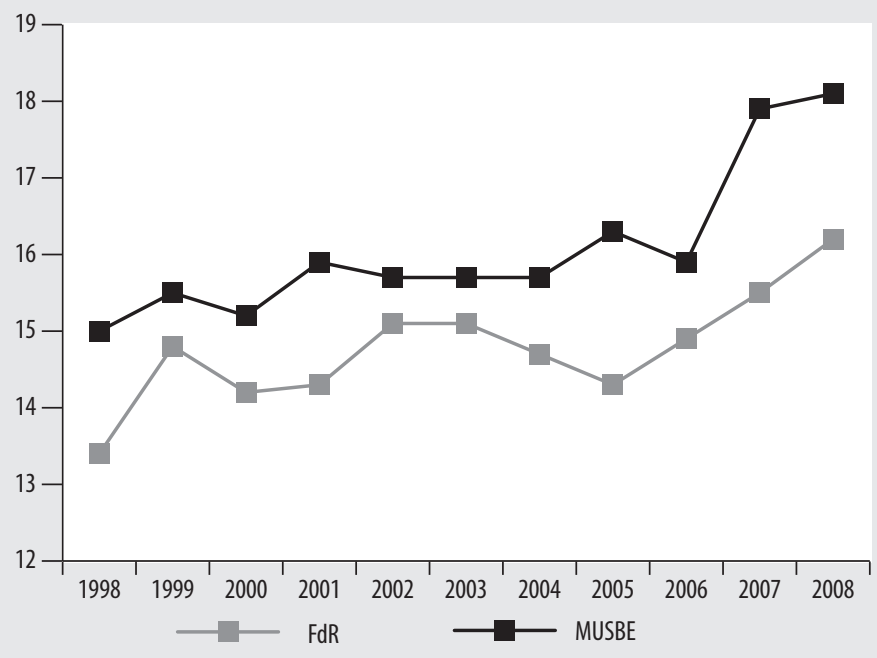

Uurloon afgerond op 10 Eurocent.

\section{Figuur 3.7.B}

Ontwikkeling gemiddeld reëel bruto uurloon FdGW, FdG (in 2008 prijzen), 1998-2008 (€)

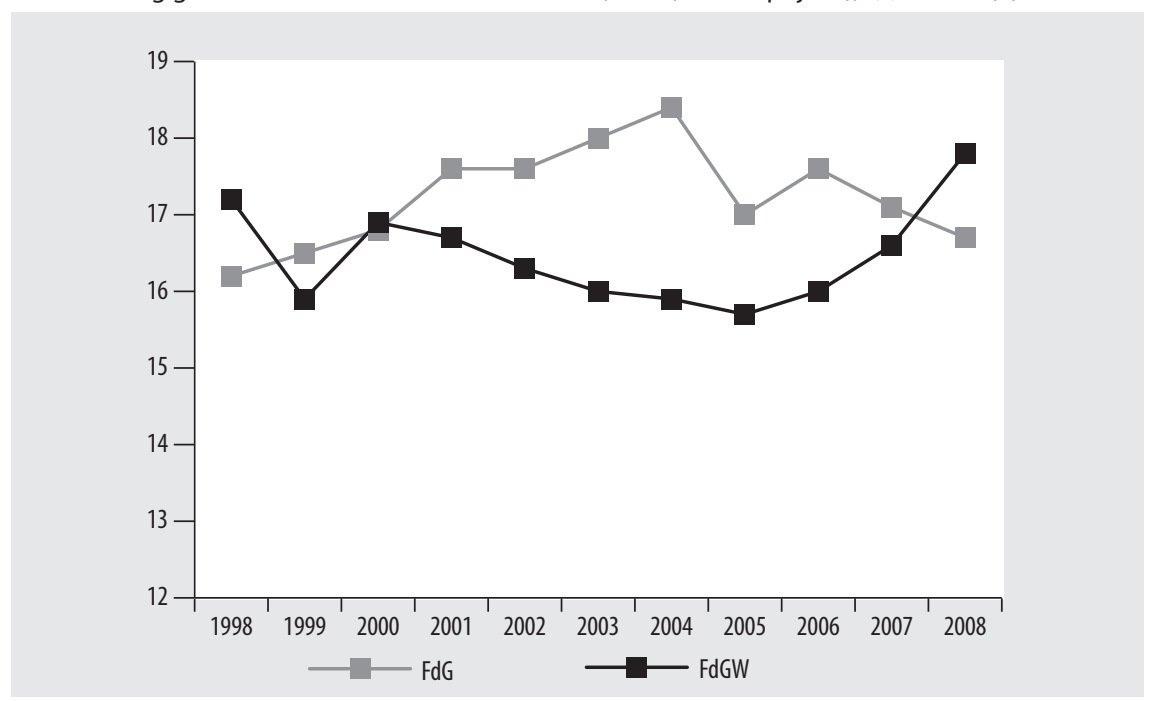

Uurloon afgerond op 10 Eurocent. 


\subsection{Alternatieven voor het aanbieden op de arbeidsmarkt: zelfstandig ondernemerschap en doorstroom naar vervolgonderwijs}

Afgestudeerden die in economisch minder goede tijden hun opleiding afronden, hebben meer moeite om werk te vinden en vinden minder vaak werk dat bij hun opleidingsniveau past. Bovendien moeten zij zich, in vergelijking met afgestudeerden die zich in economisch goede jaren op de arbeidsmarkt aanbieden, vaker tevreden stellen met relatief minder goede arbeidsvoorwaarden. De baten die men zou hebben als men zich zou aanbieden op de arbeidsmarkt zijn daarom in slechte tijden aanzienlijk lager en maken eventueel beschikbare alternatieven aantrekkelijker. In wat volgt staan we dan ook kort stil bij een tweetal mogelijke alternatieven, zelfstandig ondernemerschap en doorstromen naar vervolgonderwijs.

\section{Zelfstandig ondernemerschap}

Ongeveer IO\% van de Nederlandse beroepsbevolking is werkzaam als zelfstandig ondernemer (Blumberg \& de Graaf, 2004). Het starten van een bedrijf wordt door de overheid bevorderd omdat wordt verondersteld dat vooral kleine bedrijven verantwoordelijk zijn voor economische dynamiek en het scheppen van nieuwe banen. Kleinere bedrijven zouden beter in staat zijn zich aan te passen aan nieuwe ontwikkelingen en nieuwe technologieën te implementeren. Daarnaast is door de toegenomen welvaart de consumentenvraag naar producten en diensten steeds meer geïndividualiseerd. Kleinere bedrijven kunnen hierop beter inspelen dan grotere bedrijven.

Hieronder staat het ondernemerschap van afgestudeerden van Maastricht University centraal. Hierbij moet worden bedacht dat de beschouwde groep afgestudeerden nog maar net de opleiding heeft verlaten. Eerder onderzoek heeft uitgewezen dat zelfstandig ondernemerschap vaak wordt voorafgegaan door een periode van werken in loondienst (Bruins, 2004). Pas wanneer iemand de nodige werkervaring heeft opgedaan en het benodigde kapitaal heeft verzameld, kan deze een eigen onderneming beginnen (Blumberg \& de Graaf, 2004). Daarom blijkt conform de verwachting dat vooralsnog een zeer klein deel van de afgestudeerden circa anderhalf jaar na afstuderen werkzaam is als zelfstandig ondernemer (circa I à $2 \%$ ).

Voor de bepaling van het aandeel alumni dat werkzaam is als zelfstandig ondernemer is gevraagd naar het soort dienstverband waarin afgestudeerden werkzaam zijn Op basis hiervan is een onderscheid gemaakt tussen alumni die werkzaam zijn als zelfstandigen/freelancers (zelfstandig ondernemers) en alumni met een ander soort dienstverband.

Er kunnen overigens twee tegengestelde hypothesen worden opgesteld omtrent de relatie tussen de conjunctuur en de keuze voor het ondernemerschap. De eerste hypo- 
these luidt dat een gunstige conjunctuur een positieve invloed heeft op de keuze voor het ondernemerschap. Volgens deze hypothese kiest men vaker voor het ondernemerschap vanwege de gunstige situatie van het moment. De tweede hypothese luidt dat juist een ongunstige conjunctuur een positieve invloed heeft op de keuze voor het ondernemerschap aangezien banen in loondienst minder voorhanden zijn.

Over de beschouwde periode (1998-2008) laat het aandeel van afgestudeerden die werkzaam zijn als zelfstandige/freelancer een grillig verloop zien. Zowel in economisch goede tijden als in economisch slechte tijden zien we zowel een toename als een afname van het aandeel van afgestudeerden die werkzaam zijn als zelfstandige/ freelancer. Er lijkt daarom geen directe invloed zichtbaar te zijn van de conjuncturele situatie op de kans dat afgestudeerden van Maastricht University direct met een eigen zaak beginnen.

\section{Doorstroom naar vervolgonderwijs}

Tot nu toe is besproken in hoeverre de afgestudeerden zich na het behalen van hun diploma aanbieden op de arbeidsmarkt. Dit aanbod neemt de vorm aan van een (al dan niet vaste) baan in loondienst, een eigen bedrijf of werkloosheid. Afgestudeerden hebben echter ook de keuze om zich (nog) niet aan te bieden op de arbeidsmarkt. Hieronder gaan we in op de vraag in hoeverre de recente verslechtering van de economie in Nederland gepaard zal gaan met verschuivingen in het studiekeuzegedrag van afgestudeerden. Er zijn twee mogelijke effecten te verwachten. Ten eerste kan een afnemende economische groei het voor afgestudeerden aantrekkelijker maken om na het behalen van het diploma hun carrière in een vervolgopleiding voort te zetten in plaats van zich aan te bieden op de arbeidsmarkt. Ook kan een afnemende economische groei verder lerende afgestudeerden afschrikken om een vervolgopleiding te kiezen die opleidt voor sectoren die relatief zwaarder getroffen worden door een recessie (bijvoorbeeld economie).

In figuur 3.8 is te zien dat de deelname aan vervolgonderwijs door afgestudeerden vanaf 1998 geleidelijk aan toeneemt, weliswaar niet gestaag, maar met enige golfbeweging. Er is dus sprake van een algemene trend waarin afgestudeerden steeds vaker doorleren, en deze trend lijkt niet te worden beïnvloed door de conjuncturele situatie. 
Figuur 3.8

Ontwikkeling van de deelname aan vervolgonderwijs, 1998-2008 (\%)

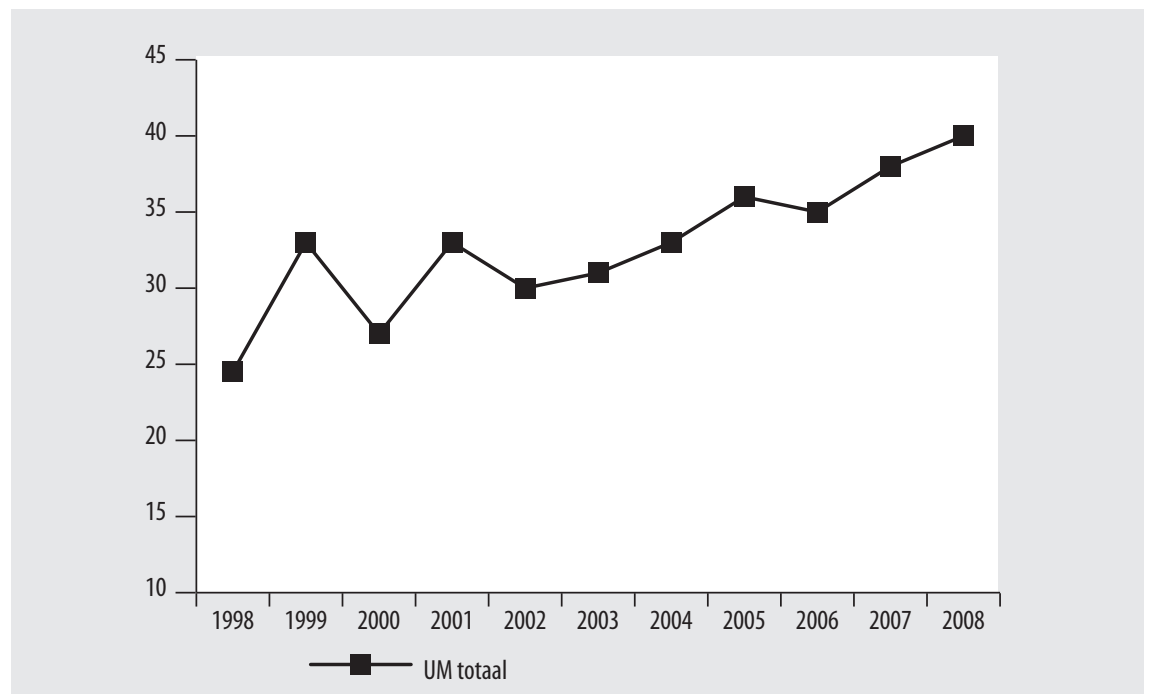

\subsection{Slechte start op de arbeidsmarkt: Effecten op middellange termijn}

Tot zover heeft onze discussie laten zien dat de afgestudeerden van Maastricht University in tijden van een economische crisis een duidelijk slechtere start op de arbeidsmarkt kennen dan in goede jaren. Dit geldt in het bijzonder voor de afgestudeerde economen, psychologen en juristen. Maar welke consequenties heeft een slechte start voor hen op de middellange termijn. Loopt hun arbeidsmarktcarrière daardoor aanzienlijk schade op of lukt het hun om de achterstand snel in te lopen. Om hier verder inzicht in te verschaffen analyseren we met behulp van longitudinale data kort de situatie van een tweetal groepen afgestudeerden vijf jaar nadat ze hun diploma hebben behaald: a) de afgestudeerden van de studiejaren 1999-2000 en 2000-200I die (met uitzondering van de afgestudeerden die in de zomer van 200 hun diploma behaalden) zich op de arbeidsmarkt konden aanbieden in tijden van sterke economische groei en b) de afgestudeerden van de studiejaren 200I-2002 en 20022003 die in een tijd van duidelijk minder economische groei hun diploma behaalden. De eerste groep afgestudeerden werd in 2006/2007 (voorjaar) bevraagd en de tweede groep in 2008/2009 (voorjaar). Voor alle meetmomenten geldt dat de economische situatie in Nederland vijf jaar na hun afstuderen als goed gekarakteriseerd kan worden.

De resultaten in tabel 3.5 geven zeker hoop voor iedereen die in moeilijke economische tijden aan Maastricht University afstudeert. Er is namelijk, zowel gemiddeld over de afgestudeerden van Maastricht University als per onderscheiden faculteit, geen verschil in de arbeidsmarktsituatie 5 jaar na afstuderen te vinden tussen de groep 
afgestudeerden die in economisch goede jaren de arbeidsmarkt hebben betreden en de groep afgestudeerden die in economisch slechte jaren de arbeidsmarkt hebben betreden. Een moeilijke start lijkt daarmee al na een vijftal jaren geen sporen meer achter te laten. Deze bevindingen sporen met eerder onderzoek. Voor Nederland laten bijvoorbeeld Schils, Fouarge en Kerkhofs (2006) zien dat werkloosheid een nadelig effect heeft op de baankans later in de loopbaan, maar dat dit negatief effect na enige tijd (zes jaar) verdwijnt. Voor Duitsland laten von Wachter en Bender (2006) zien dat werkloosheid voor jongeren aan het begin van de carrière een lager loon tot gevolg heeft. Echter deze achterstand wordt door jongeren weer binnen vijf jaar ingehaald.

Tabel 3.5

Slechte start/goede start: Consequenties op middellange termijn

\begin{tabular}{|c|c|c|c|c|c|c|}
\hline & FdG & FdGW & $\mathrm{FdP}$ & $\mathrm{FdR}$ & MUSBE & Totaal \\
\hline \multicolumn{7}{|l|}{ Goede start } \\
\hline Werkloos (\%) & 0 & 1 & 2 & 0 & 2 & 1 \\
\hline Vaste Baan (\%) & 56 & 72 & 51 & 86 & 92 & 76 \\
\hline Werk op niveau (\%) & 100 & 77 & 95 & 90 & 84 & 84 \\
\hline Leidinggeven (\%) & 27 & 28 & 20 & 19 & 35 & 27 \\
\hline Carrièreperspectieven (\%) & 79 & 57 & 60 & 65 & 86 & 67 \\
\hline \multicolumn{7}{|l|}{ Slechte start } \\
\hline Werkloos (\%) & 0 & 2 & 3 & 1 & 1 & 1 \\
\hline Vaste Baan (\%) & 51 & 71 & 64 & 88 & 89 & 76 \\
\hline Werk op niveau (\%) & 100 & 79 & 88 & 82 & 83 & 84 \\
\hline Leidinggeven (\%) & 20 & 23 & 29 & 27 & 42 & 29 \\
\hline Carrièreperspectieven (\%) & 82 & 55 & 60 & 61 & 80 & 67 \\
\hline
\end{tabular}

\subsection{Samenvatting en conclusies}

Het conjuncturele verloop kent in de afgelopen is jaar een economisch slechte periode, namelijk het begin van het nieuwe millennium (200I-2005). Door na te gaan hoe de arbeidsmarktintrede van afgestudeerden van Maastricht University op deze mindere periode heeft gereageerd, worden indicaties verkregen van de effecten van een economische crisis voor hun arbeidsmarktintrede. Hierbij is gekeken naar de kans op werk en werkzekerheid, de aansluiting tussen opleiding en werk, de beloning en naar de vraag of in economisch mindere tijden de doorstroom naar vervolgonderwijs en het zelfstandig ondernemerschap als alternatieve opties interessanter worden. 
De conjunctureel slechte periode van 200I-2005 heeft:

- geen duidelijk effect op de mate waarin afgestudeerden zich aanbieden op de reguliere arbeidsmarkt, geïndiceerd door het aandeel dat voor zichzelf begint of besluit de arbeidsmarktintrede uit te stellen door verder onderwijs te gaan volgen;

- voor de aanbieders op de arbeidsmarkt echter wel negatieve gevolgen gehad voor hun kans op werk, de zekerheid van hun werk, het niveau van hun werk en hun beloning: afgestudeerden die in economisch minder goede tijden hun opleiding afronden, hebben meer moeite om werk te vinden en vinden minder vaak werk dat bij hun opleidingsniveau past. Bovendien moeten zij zich, in vergelijking met afgestudeerden die zich in economisch goede jaren op de arbeidsmarkt aanbieden, vaker tevreden stellen met relatief minder goede arbeidsvoorwaarden (minder baanzekerheid en stagnerende beloning).

Overigens lijken de nadelige gevolgen van een start op de arbeidsmarkt onder moeilijke conjuncturele omstandigheden al na een vijftal jaren te zijn weggeëbd. 


\section{Succes- en beschermende factoren voor arbeidsmarktintrede}

\subsection{Inleiding}

Macro-economische shocks hebben gevolgen voor de arbeidsmarktintrede van afgestudeerden van Maastricht University. Ze dienen langer te zoeken naar werk, zijn vaker werkloos en worden vaker gedwongen om een functie aan te nemen die niet per definitie een universitair diploma vereist. Natuurlijk zijn de gevolgen van een macroeconomische shock niet voor iedereen van gelijke impact. Zo verschillen de afgestudeerden bijvoorbeeld in de hoeveelheid menselijk kapitaal waarover zij beschikken. Hierbij kan worden gedacht aan het niveau maar ook aan het type competenties die zij bezitten of de buitenschoolse activiteiten waaraan men tijdens de studie heeft deelgenomen. Omdat factoren die de transitie van universiteit naar werk in algemene zin versoepelen in de regel ook de factoren zijn die in tijden van economische problemen een extra beschermende werking bieden, bespreken we in dit hoofdstuk in eerste instantie succesfactoren in het algemeen. Waar mogelijk zullen we echter ook nagaan in hoeverre bepaalde factoren een additionele beschermende werking bieden in tijden van laagconjunctuur. Centraal in onze discussie staat verder een tweetal factoren die Maastricht University hoog in het vaandel heeft staan. Aan de ene kant is dat de leeromgeving. Zeker op universiteitsniveau biedt Maastricht University met haar 'probleemgestuurd onderwijs' namelijk een uitzonderlijke leeromgeving. Het tweede aspect is 'internationalisering'. Het is dan ook interessant om na te gaan hoe beide factoren, leeromgeving en internationalisering, een succesvolle arbeidsmarktintrede kunnen stimuleren.

De onderstaande discussie vindt vooral plaats aan de hand van een aantal eerdere publicaties. In eerste instantie betreft dit de publicatie Discipline-specific or Academic? Acquisition, Role and Value of Higher Education Competencies (Meng, 2005) en aan de andere hand de publicatie Schoolverlaters tussen onderwijs en arbeidsmarkt 2008 (ROA, 2009). De eerste publicatie biedt een uitgebreide analyse van a) de effecten van probleemgestuurd onderwijs en b) het belang van competenties voor de intrede op de arbeidsmarkt. De laatstgenoemde publicatie geeft inzicht in succes- en beschermende factoren, gerelateerd aan de individuele afgestudeerden en aan de opleiding die men heeft gevolgd. De combinatie van deze twee publicaties biedt dan ook tot bepaalde hoogte de mogelijkheid om een relatie tussen de leeromgeving, bescher- 
mende factoren en het type en niveau van competenties die een afgestudeerde bezit te maken.

De opbouw van het hoofdstuk is als volgt. In eerste instantie staan we kort stil bij de vraag welke type arbeidsmarkt de Nederlandse afgestudeerden in het algemeen, en de afgestudeerden van Maastricht University in het bijzonder, betreden. Deze vraag is van belang aangezien we daardoor het belang van bepaalde competenties (meer specifiek het relatieve belang van vakspecifieke competenties en van academische competenties) kunnen schetsen. Onder vakspecifieke competenties worden in dit hoofdstuk daarbij, tenzij anders vermeld, competenties zoals 'vakspecifieke theoretische kennis' en 'vakspecifieke kennis van methoden' begrepen. Onder academische competenties verstaan we competenties zoals 'ideeën en informatie documenteren', 'probleemoplossend vermogen', 'analytisch vermogen', 'leervermogen' en 'bespiegelend denken en eigen werk beoordelen'. Daaropvolgend staan we stil bij de vraag welke factoren tijdens de studie het type en niveau van de competenties beïnvloeden. Naast de leeromgeving zullen we hierbij specifiek aandacht besteden aan werkgerelateerde activiteiten, zoals het opdoen van relevante werkervaring door een reguliere bijbaan of het lopen van stage en aan buitenlandervaring tijdens de studie. Tot slot laten we zien dat deze activiteiten naast een eventuele invloed op het aanleren van competenties ook een rechtstreekse invloed op de arbeidsmarktintrede, en een beschermende werking in tijden van crisis, hebben.

\subsection{Vakspecifiek of academisch: De arbeidsmarkt van afgestudeerden van Maastricht University}

De rol en waarde van competenties opgedaan tijdens de studie aan een universiteit is zonder twijfel sterk gerelateerd aan het belang dat door werkgevers op de arbeidsmarkt aan verschillende typen van competenties wordt gehecht. De opzet van het hoger onderwijs dient daarom aan te sluiten bij de beoogde output en dus bij de eisen van de arbeidsmarkt. In deze lijn van argumentatie speelt het onderscheid tussen een interne arbeidsmarkt en een beroepsgerichte arbeidsmarkt een belangrijke rol.

Het onderscheid tussen deze twee typen arbeidsmarkten wordt algemeen beschouwd in termen van geïnstitutionaliseerde toegangseisen voor functies van geschoold personeel, die worden gedefinieerd als functies die taakspecifieke competenties vereisen. Opleidingskenmerken, zoals het specifieke vakgebied, bieden weinig houvast bij de allocatie van individuen over functies in interne arbeidsmarkten omdat zij functiespecificiteit ontberen.

Afgestudeerden starten in startposities binnen bedrijven en worden daar in bedrijfspecifieke competenties getraind wat mobiliteit tot hogere posities toestaat. Hoger 
onderwijs in landen met een interne arbeidsmarkt zal dan ook vooral gericht dienen te zijn op het aanleren van academische competenties welke de afgestudeerden een sterke basis geven om verder te leren. In tegenstelling hiermee vinden we in een beroepsgerichte arbeidsmarkt een sterke relatie tussen de vakspecifieke competenties die studenten leren in het onderwijs en de vakspecifieke competenties die door werkgevers worden gevraagd. Het aanleren van vakspecifieke competenties dient dan ook een centrale rol te spelen in het onderwijs in landen met een beroepsgerichte arbeidsmarkt. Natuurlijk zullen interne en beroepsgerichte arbeidsmarkten co-existeren in bepaalde landen, maar onderzoek laat zien dat de relatieve gewichten sterk verschillen tussen landen (zie bijvoorbeeld Eyraud, Marsden and Sylvestre, I990). Gangl (200I) laat dan ook zien dat de Europese landen te onderscheiden zijn in beroepsgerichte arbeidsmarkt landen (bijvoorbeeld Nederland, Duitsland en Oostenrijk) en interne arbeidsmarkt landen (bijvoorbeeld Frankrijk of Engeland).

Op basis van het onderscheid van arbeidsmarkten in interne en beroepsgerichte arbeidsmarkten dienen we in eerste instantie ervan uit te gaan dat vakspecifieke competenties voor afgestudeerden van Maastricht University die zich op de Nederlandse maar ook bijvoorbeeld op de Duitse arbeidsmarkt aanbieden van belang zijn. Dit is ook precies een van de centrale uitkomsten die in Meng (2005) worden gepresenteerd. Meng (2005) veronderstelt dat het loon dat de afgestudeerden ontvangen een goede indicator is voor de productieve waarde die aan hen wordt toegekend. Op basis van deze veronderstelling wordt onderzocht in hoeverre er een relatie bestaat tussen de opgedane competenties en de beloning in het werk. Verrassend laten de analyses in eerste instantie zien dat er noch voor het niveau van academische competenties, noch voor het niveau van vakspecifieke competenties dat Nederlandse studenten op het moment van afstuderen bezitten een rechtstreeks verband kan worden vastgesteld met het salarisniveau van de werkenden zo'n 3 jaar later. Echter, de analyses laten zien dat een tekort aan hetzij het type, hetzij het niveau van vakspecifieke competenties in relatie tot het gevraagde type of niveau in Nederland leidt tot een aanzienlijk lager salarisniveau. Deze uitkomsten zijn kenmerkend voor landen zoals Nederland of Duitsland met een beroepsgerichte arbeidsmarkt, maar worden niet aangetroffen in landen met een interne arbeidsmarkt, zoals Engeland. Met andere woorden, van Nederlandse afgestudeerden wordt verwacht dat zij op heel korte termijn nadat zij de arbeidsmark hebben betreden hun vakspecifieke competenties direct kunnen inzetten. Indien zij hierbij een tekort hebben, dat dan door onverwachte en kostbare training moet worden aangevuld, worden zij hiervoor in hun loon gekort. De toewijzing van afgestudeerden aan verschillende beroepenvelden in Nederland speelt dan ook een belangrijke rol. Tabel 4.I (kolom 2) vat samen welke rol hierbij de opgedane competenties in Nederland spelen. 
Tabel 4.1

Vakspecifieke en academische competenties: rol op de beroepsgerichte arbeidsmarkt

Kans op werken binnen eigen domein Kans op volgen van additioneel training

$\begin{array}{lcc}\text { Niveau van vakspecifieke competenties } & +++ & 0 \\ \text { Niveau van academische competenties } & -- & +++ \\ +/-=\text { positief/negatief significant effect } & \\ \text { o = geen significant effect } & \\ \text { Bron: Meng (2005) } & \end{array}$

Een hoog niveau van vakspecifieke competenties verhoogt aanzienlijk de kans voor de afgestudeerde dat hij of zij een functie kan bemachtigen binnen zijn eigen vakgebied. Omdat dit beter betaalde banen zijn, is het uit financieel oogpunt voor afgestudeerden belangrijk om hiervoor te worden geselecteerd. Dit resultaat ondersteunt ook het feit dat het nut van vakspecifieke competenties vaak gelimiteerd is tot een bepaald beroependomein. Opvallend is daarnaast dat een hoog niveau van academische competenties de kans verhoogt dat men buiten het eigen vakgebied werkzaam wordt. Academische competenties zijn dan ook van waarde in een bredere range van beroepen en, gezien de hier gebruikte definitie van academische competenties met een sterke nadruk op competenties zoals 'leervermogen', 'probleemoplossend vermogen' en 'analytische competenties', zijn daarmee van toegevoegde waarde buiten het eigen domein in het kader van het aanleren van nieuwe competenties.

Tot zover laten de resultaten vooral het belang van vakspecifieke competenties voor de afgestudeerden van Maastricht University zien. De vraag is dan ook wat de toegevoegde waarde van academische competenties is. Immers, de afgelopen decennia heeft de toenemende kritiek op traditionele onderwijsmethoden geleid tot een brede invoering van activerende leermethoden zoals probleemgestuurd en projectgestuurd onderwijs, waarbij de student centraal wordt gesteld en van hem/haar wordt verwacht dat hij/zij een actieve ontdekker is in plaats van iemand die passief met kennis wordt gevoerd. Van deze activerende leeromgevingen werd verwacht dat zij doelmatiger zijn in het bijbrengen van competenties in het algemeen en van academische competenties in het bijzonder. Het oorspronkelijke bestaansrecht van Maastricht University is deels zelfs gebaseerd op het aanbieden van een activerende leeromgeving. Kolom 3 van tabel 4.I laat zien dat academische competenties die zijn verkregen in het hoger onderwijs een rol spelen bij de selectie voor scholing, hetgeen op zichzelf bijdraagt aan een verhoging van de productiviteit en derhalve van het salaris. Scholing en het niveau van academische competenties die zijn opgedaan in het hoger onderwijs vullen elkaar dus aan en academische competenties worden gebruikt om de vakspecifieke competenties van afgestudeerden aan te passen aan de eisen van de arbeidsmarkt. In tegenstelling tot de bevindingen met betrekking tot vakspecifieke competenties laat Meng (2005) zien dat deze resultaten niet afhankelijk zijn van de competentiegerichtheid van het onderwijssysteem of van de institutionele instelling van de arbeidsmarkt. Analyses van Heijke, Meng en Ramaekers (2003) ondersteunen deze resultaten 
en bieden nog een verdere toegevoegde waarde van academische competenties. Zij laten zien dat naast vakspecifieke competenties ook management competenties een aanzienlijke waarde op de arbeidsmarkt kennen, maar dat dit type competenties effectiever in een werkomgeving dan in een onderwijsomgeving kan worden aangeleerd. Academische competenties, aangeleerd tijdens de studie aan een universiteit, kunnen daarbij een belangrijke ondersteunende rol spelen. Doordat afgestudeerden met een hoog niveau aan academische competenties een stevige basis kennen om verder te leren, zullen zij management competenties in een werkomgeving sneller verwerven. Hierdoor ontstaat een verdere indirecte waarde van academische competenties, aangeleerd tijdens de studie.

Tot slot wordt het belang van een hoog niveau van competenties voor de intrede op de arbeidsmarkt op indirecte wijze ook door de resultaten in het rapport Schoolverlaters tussen onderwijs en arbeidsmarkt 2008 (ROA, 2009) bevestigd. Gezien de significante correlatie tussen een hoog niveau van competenties aan het einde van de studie en het afronden van de studie met goede cijfers, kan het positieve effect van goede cijfers op de arbeidsmarktintrede in deze rapportage als een verdere onderbouwing van de relevantie van competenties gezien worden. Het gunstige effect van goede cijfers wordt ten slotte nog versterkt tijdens een recessie. Universitaire afgestudeerden met goede cijfers worden dan extra beschermd tegen werkloosheid. Goede cijfers betekenen bovendien een extra bescherming tegen werk onder niveau in tijden van laagconjunctuur. Studenten doen er wellicht verstandig aan om niet al te gauw genoegen te nemen met een zesje op hun tentamens.

Voor het gros van de afgestudeerden van Maastricht University (rond de 90\%) die zich op de arbeidsmarkt in Nederland dan wel de direct omringende landen (Duitsland, België) aanbieden, lijkt het bezitten van een combinatie van een hoog niveau van vakspecifieke competenties en van academische competenties dan ook van groot belang.

Gegeven het feit dat de overgang van hoger onderwijs naar werk plaatsvindt in een context met asymmetrische en onvolledige informatie aan beide kanten van de markt, zullen naast individuele kenmerken qua competenties groepskenmerken relevante signalen kunnen afgeven aan werkgevers. Het is dan ook niet genoeg dat een opleiding zich richt op het aanleren van de competenties die op de arbeidsmarkt gevraagd worden. Opleidingen moeten bij voorkeur ook een groep afgestudeerden afleveren die sterk overeenkomt met betrekking tot de centrale competenties die zij bezitten. Opleidingen met een relatief homogene groep van afgestudeerden wat het type en niveau van competenties betreft, bieden werkgevers beter inzicht in de te verwachten werkelijke productieve mogelijkheden van afgestudeerden, waardoor de selectie- en aanpassingskosten afnemen en werknemers een hogere beloning kunnen ontvangen. Voor opleidingen die hun afgestudeerden voor een beroepsgerichte arbeidsmarkt 
opleiden dient de voorbereiding van afgestudeerden gekoppeld te zijn aan vooral gestandaardiseerde resultaten op het gebied van vakspecifieke competenties.

\subsection{Productie van vakspecifieke en academische competenties in het hoger onderwijs}

Vakspecifieke en academische competenties spelen een belangrijke rol in de overgang van universiteit naar arbeidsmarkt. De vraag dringt zich dan ook op hoe deze competenties effectief binnen universiteiten geleerd kunnen worden. Navolgend gaan we in op een tweetal factoren dat daarbij een centrale rol speelt. In eerste instantie stellen we de vraag of een leeromgeving ('probleemgestuurd onderwijs') zoals Maastricht University kent een geschikte manier is om de vereiste combinatie van competenties te leren. Daarnaast gaan we in op de vraag welke rol werkervaring tijdens de studie maar ook buitenlandervaring hierbij kan spelen.

\subsubsection{De rol van de leeromgeving}

Gegeven dat tijd, inzet van personeel en financieel kapitaal in het hoger onderwijs aan limieten gebonden is, stelt zich de vraag of het aanleren van de steeds vaker gevraagde academische competenties ten koste mag gaan van het aanleren van vakspecifieke competenties. Met andere woorden, dienen de universiteiten een trade-off te maken en zich te concentreren op opleidingen die de afgestudeerden voorbereiden op bepaalde, maar smalle, beroepsgroepen of op opleidingen die de afgestudeerden afleveren als flexibele academische professionals. Tegelijkertijd met de toenemende vraag naar academische en generieke competenties is er ook een toenemende kritiek luid geworden op de traditionele manieren van lesgeven. Dit heeft in de laatste jaren tot toenemende inzet van nieuwe leeromgevingen geleid. Het probleemgestuurd onderwijs van Maastricht University is daarbij een voorbeeld van wat Vaatstra en de Vries (2003) een activerende onderwijsmethode noemen. Zij stellen dat deze onderwijsmethodes door verschillende onderwijswetenschappers worden aangedragen als voorbeelden van leeromgevingen waarin studenten leren om multidisciplinaire kennis toe te passen op problemen. Een tweede voorbeeld is projectonderwijs. In beide methodes verwerven studenten niet alleen beroepsspecifieke competenties maar vooral ook generieke competenties (Delhoofen, I996; Everwijn, I999; Van Woerden, 1997).

Meng (2005) onderscheidt in zijn analyse een viertal leeromgevingen aan de hand van een tweetal aspecten: a) de vraag in welke mate probleemgestuurd dan wel projectgestuurd onderwijs plaatsvindt en b) de vraag in welke mate de leraar de centrale bron van informatie is. Twee van de onderscheiden leeromgevingen (zie matrix 4.I) zijn typisch activerende leeromgevingen: a) PGO zonder leraar en b) PGO met leraar. Zij 
onderscheiden zich daarbij door de rol die aan de leraar toegekend wordt. In het eerste geval is de leraar een pure procescoördinator. In het tweede geval vormt hij ook een belangrijke bron van kennis. Beide leeromgevingen zullen aan Maastricht University voorkomen. De ervaringen die studenten met de ene of de andere activerende leeromgeving hebben, zijn vooral afhankelijk van de gemiddelde opzet van de vakken die zij gevolgd hebben en de vraag in hoeverre de gemiddelde leraar zich zelf als bron van kennis wilde inzetten.

De andere twee leeromgevingen zijn in eerste instantie niet-activerend. De traditionele leeromgeving kenmerkt zich vooral door colleges en zelfstudie uit boeken. De schoolklas leeromgeving kent vaker kleinere klassen met een leraar die in klassikale stijl kennis overbrengt. De schoolklas leeromgeving komt overigens bij universiteiten relatief gezien zelden voor, maar speelt in Nederland in het hoger beroepsonderwijs wel degelijk een belangrijke rol. Belangrijk is om direct vast te stellen dat de scheiding tussen de schoolklas leeromgeving en de leeromgeving 'PGO met leraar' natuurlijk nogal dun is. Immers, centraal voor PGO zijn groepsbijeenkomsten waar gauw het gevaar schuilt dat een leraar die als bron van informatie wenst te dienen de grens overschrijdt en de activerende leeromgeving omtovert in een klassikale leeromgeving.

\section{Matrix 4.1}

4 verschillende leeromgevingen

\begin{tabular}{|l|l|l|l|}
\hline \multicolumn{2}{|c|}{} & \multicolumn{2}{|l|}{ Nadruk op probleemgestuurd dan wel projectgestuurd onderwijs } \\
\cline { 3 - 4 } \cline { 3 - 4 } & Zwak & Sterk \\
\hline $\begin{array}{l}\text { Nadruk op leraar als centraal bron van } \\
\text { informatie }\end{array}$ & Zwak & Traditioneel & PG0 zonder leraar \\
\cline { 2 - 4 } & Sterk & Schoolklas & PG0 met leraar \\
\hline
\end{tabular}

Bron: Meng (2005)

Is probleemgestuurd onderwijs inderdaad een effectieve manier om academische competenties aan te leren, en kan dit zonder druk op het niveau van vakspecifieke competenties te leggen. Tabel 4.2 vat wat deze vraag betreft de belangrijkste resultaten van Meng (2005) samen. In eerste instantie is direct zichtbaar dat een activerende leeromgeving ertoe leidt dat de studenten aan het einde van de studie een hoger niveau aan academische competenties bezitten dan de studenten die geen activerende leeromgeving kennen. PGO, zij het met of zonder sterke rol van de leraar, bereikt daarmee wat de doelstelling is. De resultaten met betrekking tot het niveau van vakspecifieke competenties neemt daarna de kritiek weg dat de winst op het aanleren van academische competenties gepaard gaat met een verlies op vakspecifieke competenties. PGO zonder een leraar als belangrijke bron van kennis doet het daarbij net zo goed als de niet-activerende leeromgevingen. Indien de leraar in het probleemgestuurd onderwijs echter naast zijn rol als procescoördinator ook bron van kennis is, bezitten de studenten aan het einde van de studie zelfs een verhoogd niveau van vakspecifieke competenties. 
Tabel 4.2

Invloed van PGO op niveau van competenties

$\begin{array}{llc}\text { PG0 zonder leraar } & \text { Ref. } & \text { Ref. } \\ \text { PG0 met leraar } & 0 & +++ \\ \text { Schoolklas type } & --- & 0 \\ \text { Traditionele type } & -- & 0 \\ +/-=\text { positief/negatief significant effect } & & \\ \begin{array}{l}\text { o = geen significant effect } \\ \text { Bron: Meng (2005) }\end{array} & & \end{array}$

Een eerste belangrijk discussiepunt is of de resultaten gedragen worden door de grote studierichtingen. Na aanleiding van de analyses in Meng (2005) zijn hiervoor verschillende robuustheid analyses uitgevoerd. Deze analyses lieten keer op keer zien dat de resultaten met betrekking tot de leeromgeving sterk vergelijkbaar zijn als er bijvoorbeeld op een bepaalde studierichting ingezoomd wordt. Ook zijn de resultaten tussen landen overdraagbaar of tussen onderwijstypes, zoals het universitaire onderwijs en het hoger beroepsonderwijs in Nederland.

Een tweede belangrijk discussiepunt is natuurlijk of de bovenstaande resultaten niet beïnvloed zijn door zelfselectie van studenten in activerende dan wel niet activerende leeromgevingen. Met andere woorden, wie kiest voor een activerende leeromgeving, zoals het probleemgestuurd onderwijs aan Maastricht University? Vaatstra en de Vries (2003) citeren bijvoorbeeld onderzoek van Cariaga-Lo e.a. (1996) waaruit blijkt dat beginnende studenten van een medisch curriculum met probleemgestuurd onderwijs al andere, niet-cognitieve competenties bezitten dan medische studenten die een conventionele onderwijsmethode volgen. In dit geval is het gevaar aanwezig dat de gepresenteerde resultaten niet uitsluitend de uitkomst van de leeromgeving weergeven maar deels een gevolg zijn van achtergrondverschillen tussen de studenten. In de analyses van Meng (2005) wordt hiervoor echter tot bepaalde hoogte gecontroleerd. Zo worden verschillende achtergrondkenmerken, zoals het type vooropleiding en het eindcijfer in de vooropleiding in de analyses meegenomen. Daarnaast wordt er voor gecontroleerd dat een hoog niveau aan academische competenties het aanleren van vakspecifieke competenties vereenvoudigd. Verder laten de analyses op basis van het databestand dat Meng (2005) gebruikte geen onderscheid in de bekende achtergrondkenmerken van de studenten zien tussen de studenten die voor een activerende leeromgeving hebben gekozen en de studenten die dit niet deden. Tot slot is het van belang om op te merken dat het onderscheid in activerende versus niet-activerende leeromgevingen in Meng (2005) niet op basis van externe gegevens over universiteiten maar op basis van de ervaring die de studenten hebben opgedaan is gemaakt. Ook in het geval van Maastricht University die zich als 'probleemgestuurde universiteit' profileert, zien studenten zich eerder in een schoolklas leeromgeving dan in een activerende leeromgeving. Reden hiervoor is de smalle grens tussen een probleemgestuurde 
leeromgeving met een actieve leraar en de schoolkas leeromgeving zonder activerende aspecten.

Een laatste punt van aandacht is de vraag of probleemgestuurd onderwijs naast de sterke invloed op academische competenties ook een toegevoegde waarde heeft op andere generieke competenties, zoals communicatiecompetenties of managementcompetenties. Analyses in Heijke, Meng en Ramaekers (2003) bevestigen dit. Studenten in activerende leeromgevingen bezitten gemiddeld aan het einde van de studie ook betere mondelinge competenties en managementcompetenties. Echter, bij de laatstgenoemde competenties dient nog een keer opgemerkt te worden dat deze effectiever in een werkomgeving dan in een onderwijsomgeving aangeleerd kunnen worden.

\subsubsection{De rol van werkervaring en stage}

\section{Direct effect op arbeidsmarktintrede}

Vaardigheden en kennis kunnen niet alleen in de collegezaal aangeleerd worden. Activiteiten die studenten tijdens hun studie buiten de muren van de universiteit opdoen, kunnen hierbij een belangrijke rol spelen. We beperken ons in de discussie tot een drietal activiteiten. Ten eerste tot het wel of geen stage lopen tijdens de opleiding. Naast een stage kunnen studenten via een reguliere baan voor het vakgebied relevante werkervaring opdoen tijdens de opleiding. Een derde vorm van ervaring die van nut kan zijn is bestuurlijke ervaring, bijvoorbeeld als voorzitter of secretaris van een studentenvereniging. Naast de mogelijke invloed die deze activiteiten op het opdoen van competenties hebben, kennen zij ook een rechtstreekse invloed op de arbeidsmarktintrede. In het rapport Schoolverlaters tussen onderwijs en arbeidsmarkt 2008 (ROA, 2009) is uitgebreid op dit aspect ingegaan. De vraag was daarbij welke factoren afgestudeerden van het universitair onderwijs in Nederland beschermen voor moeilijkheden bij het intreden op de arbeidsmarkt. Omdat factoren die een beschermende werking bieden in gunstigere economische tijden ook tijdens een recessie vaak goed zullen werken, is in het voornoemde rapport eerst gezocht naar factoren die de transitie van universiteit naar werk in algemene zin versoepelen. Tabel 4.3 vat een aantal van deze algemene effecten op basis van deze analyses samen.

Tabel 4.3

Succesfactoren voor de transitie van onderwijs naar arbeidsmarkt

\begin{tabular}{lccc} 
& Kans op werk & Werk op niveau & Uurloon \\
\cline { 2 - 2 } & + & + & + \\
Relevante Werkervaring & + & + & 0
\end{tabular}

$+/-=$ positief/negatief significant effect

$\mathrm{o}=$ geen significant effect

Bron: Schoolverlaters tussen onderwijs en arbeidsmarkt 2008, ROA,(2009) 
Naast deze algemene effecten is nagegaan in hoeverre bepaalde factoren een additionele beschermende werking bieden in tijden van laagconjunctuur. Dit bleek in een aantal gevallen inderdaad het geval te zijn. Het algemene loonvoordeel voor academici die tijdens de WO-opleiding relevante werkervaring hebben opgedaan, wordt tijdens een recessie verder versterkt. Het lijkt alsof zulke ervaring dan bescherming biedt tegen de loonstagnatie die normaliter in deze tijden optreedt. Hetzelfde geldt voor het positieve effect van het volgen van een WO-opleiding met veel stages op de kans op een baan op universitair niveau.

\section{Maastricht University versus Nederland}

Bovenvermelde samenvatting van eerder verrichte analyses heeft laten zien dat van deze twee activiteiten een positief effect op de arbeidsmarktintrede vast te stellen is. Maar hoe scoren de afgestudeerden van Maastricht University op deze twee activiteiten en wat is hun relatieve positie in Nederland.

\section{Werkervaring buiten studie om}

45\% van de afgestudeerden van Maastricht University (studiejaren 2006-2008) heeft, buiten een eventuele stage om, tijdens de studie werkervaring opgedaan die gerelateerd was aan de gevolgde studie (zie tabel 4.4). Aangezien deze werkervaring volgens hen gekoppeld is aan hun studie, is het aannemelijk dat de werkervaring ook een bron van studiegerelateerde competenties is. Met uitzondering van de afgestudeerden van MICC doen de studenten aan Maastricht University minder relevante werkervaring op dan de studenten van vergelijkbare opleidingen aan andere Nederlandse universiteiten. De afgestudeerden van Maastricht University kunnen daarmee minder profiteren van bijvoorbeeld het opbouwen van een eigen netwerk met (potentiële) werkgevers. Maar waarom scoren de afgestudeerden van Maastricht University op dit aspect lager? Verdere analyses hebben laten zien dat het Nederlands gemiddelde vooral door de afgestudeerden van de universiteiten in de Randstad omhoog geduwd worden. Studeren in de Randstad biedt blijkbaar een grotere kans om een reguliere bijbaan te hebben die aan de studie gerelateerd is. Of met andere woorden, een nadeel voor studenten aan meer perifere universiteiten, zoals Maastricht University, kan zijn dat zij in een omgeving studeren waarin opties voor het opdoen van relevante werkervaring beperkter zijn.

\section{Stage}

Naast deze 'reguliere' werkzaamheden heeft $58 \%$ van de afgestudeerden minstens een keer een stage in Nederland gevolgd en heeft 31\% een stage in het buitenland gevolgd. De afgestudeerden van Maastricht University kenmerken zich daarbij vooral door een in vergelijking met landelijk hoog percentage van studenten die een stage in het 
buitenland volgen, namelijk bijna een op de drie. Wat de stages betreft, stelt zich ook hier weer de vraag in hoeverre deze activiteit naast een blijkbaar rechtstreekse invloed op de arbeidsmarktintrede ook de acquisitie van competenties beïnvloedt. In tegenstelling tot reguliere werkzaamheden dienen we namelijk bij stages rekening te houden met het gegeven dat deze activiteit, tenzij deze in de onderwijsvrije periode plaatsvindt, in de regel een vervanging van formeel onderwijs vormt. Deze trade-off die in eerste instantie een positief teken laat zien wat de arbeidsmarktintrede betreft, zal eventueel getemperd kunnen worden door een negatieve invloed op de acquisitie van competenties.

\section{Tabel 4.4}

Succes- en beschermende factoren tijdens laagconjunctuur, naar faculteit

\begin{tabular}{|c|c|c|c|c|c|c|c|c|}
\hline Maastricht University & FdCMW & FdG & FdGW & $\mathrm{FdP}$ & $\mathrm{FdR}$ & MICC & MUSBE & Totaal \\
\hline $\begin{array}{l}\text { Relevante werkervaring buiten } \\
\text { studie om }\end{array}$ & 35 & 55 & 45 & 45 & 46 & 58 & 41 & 45 \\
\hline \multicolumn{9}{|l|}{ Stage } \\
\hline - waarvan in Nederland & 40 & 100 & 73 & 79 & 50 & 47 & 24 & 58 \\
\hline - waarvan in buitenland & 31 & 80 & 14 & 16 & 13 & 36 & 35 & 31 \\
\hline $\begin{array}{l}\text { Zusterfaculteiten in } \\
\text { Nederland }\end{array}$ & FdCMW & FdG & FdGW & $\mathrm{FdP}$ & $\mathrm{FdR}$ & MICC & MUSBE & Totaal \\
\hline Relevante werkervaring & 48 & 60 & 64 & 48 & 57 & 38 & 47 & 51 \\
\hline \multicolumn{9}{|l|}{ Stage } \\
\hline - waarvan in Nederland & 60 & 95 & 46 & 89 & 50 & 40 & 57 & 61 \\
\hline - waarvan in buitenland & 9 & 51 & 2 & 6 & 6 & 13 & 11 & 16 \\
\hline
\end{tabular}

\section{Indirect effect op het verwerven van competenties}

Zowel relevante werkervaring als het lopen van een stage heeft een positieve invloed op de overgang van universiteit naar werk. De vraag is echter of deze activiteiten niet ook nog een indirect effect kennen, namelijk een effect via het aanleren van competenties. Navolgend presenteren we daarom wederom een aantal resultaten uit Meng (2005) met betrekking tot de invloed van deze extra-curriculare activiteiten op het aanleren van competenties, en analyseren we welke consequenties voor Maastricht University hieraan verbonden zijn. In tabel 4.5 wordt de invloed van het gemiddeld aantal uren per week dat de student tijdens de opleiding aan reguliere betaalde werkzaamheden heeft besteed gepresenteerd. In de eerste rij gaat het daarbij om het gemiddeld aantal uren betaalde werkzaamheden zonder nader in te gaan in welke mate deze werkzaamheden gerelateerd waren aan de studie. In de tweede rij gaat het exclusief om betaalde werkzaamheden die gerelateerd zijn aan de studie. 
Werkzaamheden verrichten die niet aan de studie zijn gerelateerd nemen tijd weg van het aanleren van vakspecifieke competenties. Dat is niet per se verrassend. Immers, de student zou deze uren ook aan zelfstudie kunnen besteden en daarbij zijn vakkennis kunnen verbeteren. Verrassend is echter dat deze werkzaamheden ook negatief uitpakken voor de academische competenties, ook al is het effect slechts op IO\% niveau significant. Afgezien van het feit dat elke betaalde werkzaamheid uiteraard een inkomstenbron vormt, dient daarom vastgesteld te worden dat niet aan de studie gerelateerde werkzaamheden als zodanig als verloren tijd moeten worden beschouwd. Overigens laten Heijke, Meng en Ramaekers (2003) zien dat niet studie gerelateerde werkzaamheden ook geen positieve effecten hebben op bijvoorbeeld managementcompetenties, een type competenties dat buiten de studiesetting vaak effectiever kan worden aangeleerd. Hiertegenover staat dat studiegerelateerde werkzaamheden wel bijdragen aan het aanleren van competenties. Naast het verwachte effect op vakspecifieke competenties komt daarbij ook een sterk effect op academische competenties. Dat het hierbij ook om een duidelijk ander type werkzaamheden handelt dan niet studiegerelateerde werkzaamheden komt verder in de eerder genoemde studie van Heijke, Meng en Ramaekers (2003) naar voren. Zij laten namelijk zien dat studiegerelateerde werkzaamheden ook een effectieve manier zijn om a) mondelinge communicatievaardigheden, b) managementcompetenties en c) people skills (zoals teamwerk, tolerantie, loyaliteit of kritisch denken) op te doen. Gezien deze resultaten dient er nogmaals nadrukkelijk op te worden gewezen dat de studenten van Maastricht University relatief gezien minder studiegerelateerde werkervaring hebben dan studenten in de Randstad. Hier ligt dan ook nog een zeker ontwikkelingspotentieel voor Maastricht University.

Tabel 4.5

Invloed van reguliere betaalde werkzaamheden en stage op het niveau van competenties

$\begin{array}{lcc} & \text { Academische competenties } & \text { Vakspecifieke competenties } \\ \begin{array}{l}\text { Uren besteed aan betaalde werkzaamheden } \\ \text { Uren besteed aan studiegerelateerde werkzaamheden }\end{array} & --- \\ & +++ & 0 \\ \text { Korte stage gelopen } & 0 & -- \\ \text { Lange stage gelopen } & 0 & ++ \\ \text { Ervaring in het buitenland } & ++ \\ \text { +/- = positief/negatief significant effect } & \\ \text { o = geen significant effect } & \\ \text { Bron: Meng (2005) } & \\ \text { De resultaten in rij vier en vijf laten zien dat het lopen van een stage niet tot een } \\ \text { verhoogd competentieniveau leidt. We hebben hier al opgemerkt dat stage vaak een } \\ \text { onderdeel van het curriculum is en daarom een vervanging van formeel onderwijs. }\end{array}$


Tot slot laat tabel 4.5 twee tegengestelde invloeden zien die uitgaan van ervaring in het buitenland, zij het via een studieonderdeel dat in het buitenland wordt gevolgd of zij het via werkervaring in het buitenland. Tijd doorbrengen in het buitenland tijdens de studie lijkt een effectieve manier te zijn om academische competenties aan te leren maar lijkt tevens ten koste te gaan van vakspecifieke competenties. Overigens is het tweede effect minder sterk dan het in eerste instantie lijkt. Reden hiervoor is dat het niveau van academische competenties namelijk ook een belangrijke factor is voor het aanleren van vakspecifieke competenties. Studenten die buitenlandervaring opdoen zullen daarom na terugkomst, dankzij het hogere niveau van academische competenties, versnelt vakspecifieke competenties aanleren en een deel van het verlies kunnen compenseren. Om het uiteindelijke verlies zo klein mogelijk te houden, dient een studieverblijf in het buitenland dan ook zo vroeg mogelijk in de studie plaats te vinden.

\subsection{Conclusies}

Afgestudeerden van Maastricht University bieden zich voor meer dan 90\% op de Nederlandse, Duitse en Belgische arbeidsmarkt aan. Deze arbeidsmarkten kunnen in het algemeen als beroepsgerichte arbeidsmarkten getypeerd worden. Van afgestudeerden wordt dan ook verwacht dat zij een hoog niveau van vakspecifieke competenties meebrengen. Echter, in de afgelopen decennia is vanuit de arbeidsmarkt de verwachting onstaan dat afgestudeerden meer zijn dan jongeren die vakspecifieke competenties bezitten. Volgens Sternberg (2003) verwacht men dan ook dat scholen "a generation of experts, whose expertise will extend well beyond technical knowledge" afleveren. Naast vakspecifieke competenties zullen dan voor afgestudeerden van universiteiten academische competenties, zoals probleemoplossend vermogen, kritisch denken of leervermogen een even zo centrale rol gaan spelen, zonder daarbij de rol van vakspecifieke competenties minder te maken. Afgestudeerden van Maastricht University dienen daarom voor een succesvolle arbeidsmarktintrede een combinatie van een hoog niveau van vakspecifieke competenties en academische competenties te bezitten. Probleemgestuurd onderwijs, een van de mogelijke activerende leeromgevingen, biedt daarvoor een uitermate geschikte leeromgeving. Afgestudeerden van probleemgestuurd onderwijs hebben een hoger niveau van academische competenties dan afgestudeerden van niet-activerende leeromgevingen, zonder dat hierbij een trade-off met het aanleren van vakspecifieke competenties ontstaat. Wanneer probleemgestuurd onderwijs gecombineerd wordt met een actieve leraar die kennis, indien noodzakelijk, overdraagt en daarmee een bron van informatie naast een procescoördinator wordt, kan probleemgestuurd onderwijs zelfs tot een verhoogd niveau van vakspecifieke competenties leiden. Echter, het gevaar is aanwezig dat deze actieve leraar het activerende van het probleemgestuurd onderwijs wegneemt en de leerom- 
geving omtovert in een schoolklas leeromgeving met nadelige gevolgen voor de academische competenties.

Naast de leeromgeving speelt vooral relevante werkervaring (zij het door een reguliere betaalde functie naast de studie, zij het door stage) een belangrijke rol in de arbeidsmarktintrede. Deze factoren bieden zelfs een toegevoegde bescherming in tijden van economisch mindere jaren. Studenten van Maastricht University kennen hierbij echter het gemis van een groot aantal relevante bedrijven in de nabijheid van de universiteit. Dit in tegenstelling tot universiteiten in de Randstad. Studenten van Maastricht University dienen dit dat dan ook te compenseren door bijvoorbeeld stages die niet direct aan bedrijven in de omgeving gekoppeld zijn. Buitenlandervaring speelt daarbij voor de studenten van Maastricht University een belangrijke rol.

Overigens verhoogt relevante werkervaring het niveau van academische en vakspecifieke competenties, en heeft daarmee ook indirect een positief effect op de overgang van de universiteit naar de arbeidmarkt. 


\section{Literatuur}

Blumberg, B., Graaf, P. de (2004), Zelfstandig ondernemerschap in Nederland: Determinanten van instroom en uitstroom. Mens en Maatschappij, 79, 1, pp. 43-65.

Bradley, K., Charles, M. (2004), Uneven roads: understanding women's status in higher education. In D. Baker, B. Fuller, E. Hannum \& R. Werum (eds), Inequalities across societies: families, schools and persisting stratification, Elsevier JAI, Amsterdam, 247-274.

Bruins, A. (2004), Starten in recessie: Startende ondernemers in 2003, Zoetermeer: EIM.

Cariaga-Lo, L.D., Richards, B.F., Hollingsworth, M.A., Camp, D.L. (1996). 'Noncognitive characteristics of medical students: Entry to problem-based and lecturebased curricula', Medical Education, 30, pp. 179-186.

Delhoofen, P. (1996). De student centraal. Handboek zelfgestuurd onderwijs. Groningen: Wolters-Noordhoff.

Everwijn, S. (1999), Het hoe, wat en waarom van competentiegericht onderwijs, in: Schlusmans, K., et al (eds.), Competentiegerichte leeromgevingen, Utrecht: Uitgeverij Lemma, pp. 63-78.

Eyraud, F., Marsden, D., Sylvestre, J. (1990), Occupational and internal labour markets in Briain and France, International Labour Review, 129, pp. 501-507.

Gangl, M. (2001), European patterns of labour market entry. A dichotomy of occupationalised vs. non-occupationalised systems, European Societies, 3, pp. 471-494.

Grip, A. de, Loo, J. van, Sieben, I (2005), Arbeidsmarktmonitor Metalektro 2004, ROAR-2005/5, Researchcentrum voor Onderwijs en Arbeidsmarkt, Universiteit Maastricht.

Heijke, H., Meng, C., Ramaekers, G. (2003), An Investigation into the Role of Human Capital Competences and their Pay-Off, International Journal of Manpower, 24(7), 750-773.

Meng, C. (2005), Discipline-specific or Academic? Acquisition, Role and Value of Higher Education Competencies, ROA, Maastricht.

Ramaekers, G. (2008), Loopbanen na de Universiteit Maastricht: metingen 2006 en 2007, Maastricht: Researchcentrum voor Onderwijs en Arbeidsmarkt.

ROA (2009), Schoolverlaters tussen onderwijs en arbeidsmarkt 2008, Maastricht: Researchcentrum voor Onderwijs en Arbeidsmarkt.

Schils, T., Fouarge, D., Kerkhof, M. (2006), Loon en werk na werkloosheid, OSA rapport A221, Tilburg.

Sternberg, J. (2003), “What is an expert student?”, Educational Researcher, 32 (8), pp. 5-9.

Vaatstra, R., Vries, R. de (2003), De relatie tussen onderwijsvorm, competenties en arbeidsmarkt, Tijdschrift voor Hoger Onderwijs, 21 (1), pp. 144-158. 
Wachter, T. von, Bender, S. (2006), In the right place at the wrong time: the role of firms and luck in young worker's careers, American Economic Review, 96 (5), 1679-1705.

Woerden, W. van (1997), De ontwikkeling van activerend onderwijs: probleemgestuurd leren en projectonderwijs, in: Ten Dam, G., et al (eds.), Onderwijskunde Hoger Onderwijs, Assen: van Gorcum, pp. 186-213. 


\section{Bijlage 1}

In deze bijlage wordt ingegaan op de respons van de twee meest recente metingen onder alumni van Maastricht University die $\mathrm{I}^{1 / 2}$ jaar, $5^{1 / 2}$ jaar en IO $^{1 / 2}$ jaar eerder de opleiding hebben verlaten. Tabel B.I geeft een overzicht van het aantal alumni en de respons van de meting die eind 2008 heeft plaatsgevonden onder alumni $\mathrm{I}^{1 / 2} \mathrm{j}$ jar na afstuderen (cohort 2006-2007) en de meting die in het voorjaar van 2008 heeft plaatsgevonden onder alumni $5^{1 / 2}$ jaar na afstuderen (cohort 200I-2002) en IO $1 / 2$ jaar na afstuderen (cohort 1996-1997).

\section{Tabel B.1}

Responscijfers metingen in meetjaar 2008

\begin{tabular}{|c|c|c|c|c|c|c|}
\hline & \multicolumn{2}{|c|}{ Cohort 2006-2007 (t+1) } & \multicolumn{2}{|c|}{ Cohort 2001-2002 $(t+5)$} & \multicolumn{2}{|c|}{ Cohort 1996-1997 (t+10) } \\
\hline & $\mathrm{N}$ alumni & Respons (\%) & $\mathrm{N}$ alumni & Respons (\%) & $\mathrm{N}$ alumni & Respons (\%) \\
\hline FdCMW & 346 & 23 & 56 & 43 & 40 & 35 \\
\hline $\mathrm{FdG}$ & 262 & 44 & 208 & 44 & 149 & 35 \\
\hline FdGW & 571 & 42 & 417 & 49 & 365 & 44 \\
\hline $\mathrm{FdP}$ & 150 & 31 & 87 & 41 & - & - \\
\hline $\mathrm{FdR}$ & 365 & 30 & 258 & 41 & 249 & 35 \\
\hline MICC & 35 & 29 & 5 & 60 & 4 & 50 \\
\hline MUSBE & 579 & 25 & 457 & 44 & 314 & 40 \\
\hline Totaal & 2.308 & 32 & 1.488 & 45 & 1.121 & 39 \\
\hline
\end{tabular}

Tabel B.2 geeft een overzicht van het aantal alumni en de respons van de meting die in het voorjaar van 2009 heeft plaatsgevonden onder alumni $5^{1 / 2}$ jaar na afstuderen (cohort 2002-2003) en IO $1 / 2$ jaar na afstuderen (cohort 1997-1998). 
Bijlage 1

Tabel B.2

Responscijfers metingen in meetjaar 2009

\begin{tabular}{|lcccccc|} 
& \multicolumn{2}{c}{ Cohort 2007-2008 $(\mathrm{t}+1)$} & \multicolumn{2}{c}{ Cohort 2002-2003 $(\mathrm{t}+5)$} & \multicolumn{2}{c}{ Cohort 1997-1998 (t+10) } \\
& Nalumni & Respons (\%) & Nalumni & Respons (\%) & Nalumni & Respons (\%) \\
\hline FdCMW & - & - & 56 & 45 & 28 & 54 \\
\hline FdG & - & - & 228 & 36 & 184 & 33 \\
\hline FdGW & - & - & 411 & 47 & 314 & 42 \\
\hline FdP & - & - & 126 & 44 & - & 31 \\
\hline FdR & - & - & 258 & 34 & 227 & 15 \\
\hline MICC & - & - & 13 & 38 & 325 & 37 \\
\hline MUSBE & - & - & 501 & 43 & & 37 \\
\hline
\end{tabular}

Voor cohort 2007-2008 zijn nog geen definitieve responsgegevens beschikbaar.

Bron: ROA 